\title{
Asaltos al trópico: Petros Pharamond Blanchard, un pintor romántico francés en el México de 1838
}

\author{
Assaults on the Tropic: Petros Pharamond Blanchard, a French Romantic Painter \\ in the Mexico of $I 838$
}

Artículo recibido el I8 de enero de 20I7; devuelto para revisión el 6 de abril de 20I7; aceptado el Io de agosto de 2017, http://dx.doi.org/IO.2220I/iie.18703062e.20I8.II2.2632

Arturo Aguilar Ochoa Benemérita Universidad Autónoma de Puebla (BUAP)-Instituto de Ciencias Sociales y Humanidades, México. aragoch@hotmail.com

Líneas de investigación

Lines of research:

Publicaciones más relevantes
Artistas viajeros en el siglo xix; historia de la fotografía mexicana; historia de la vida cotidiana durante el segundo imperio mexicano; arte y litografía.

Artistic travelers in the I9th century; history of Mexican photography; History of daily life during the second Mexican empire; art and lithography.

La fotografía durante el imperio de Maximiliano (México: Universidad Nacional Autónoma de México-Instituto de Investigaciones Estéticas, 1996); "Pedro Gualdi, pintor de perspectiva en México", en El escenario urbano de Pedro Gualdi, catálogo de la exposición (México: Instituto Nacional de Bellas Artes-Museo Nacional de Arte, 1997), 8-19; “Carl Nebel”, Artes de México, núm. 80 (2005): 33-67; Las glorias nacionales o el álbum de la guerra (Colegio de Puebla/Benemérita Universidad Autónoma de Puebla, 20I2); Un instrumento de los demás Gaëtan Souchet D'Alvimar, artista y filibustero en México (México: Benemérita Universidad de Puebla-Instituto de Ciencias Sociales y Humanidades, 2016).

Resumen El texto busca rescatar la biografía y las obras hechas en México de un pintor olvidado en la historiografía sobre el tema. Ya sea que se le considere como un pintor expedicionario o un artista viajero, es poco lo que se sabía, hasta ahora, del francés Petros Pharamond Blanchard. No obstante, su trabajo es destacable por haber realizado una importante serie de tipos populares y escenas costumbristas, además de cuadros de batallas sobre la toma del puerto de Veracruz en I838 y por haber escrito un libro sobre esta expedición, el cual contiene grabados sobre el paisaje mexicano. 
Palabras clave Artista viajero; escenas costumbristas; tipos populares; cuadros de batallas; expedición francesa de I838 en México.

Abstract The text seeks to rescue the biography and works created in Mexico
by a painter forgotten to the historiography on the theme. Whether
considered an expeditionary painter or a traveling artist, so far little
is known about the Frenchman Petros Pharamond Blanchard. How-
ever, his work is remarkable for having executed an important series
on local everyday life and customs, as well as pictures of battles dur-
ing the assault on the port of Veracruz in I838. He also wrote a cele-
brated book about this expedition, which contains engravings of the
Mexican landscape.

Keywords Traveling artists; costumbrist scenes; popular types; pictures of battles; French assault on the port of Veracruz in 1838 . 
DOI: http://dx.doi.org/10.22201/iie.18703062e.2018.112.2632

\author{
ARTURO AGUILAR OCHOA \\ INSTITUTO DE CIENCIAS SOCIALES Y HUMANIDADES \\ BENEMÉRITA UNIVERSIDAD AUTÓNOMA DE PUEBLA \\ MÉXICO
}

\title{
Asaltos al trópico: Petros Pharamond Blanchard, un pintor romántico francés en el México de 1838
}

$\mathrm{D}$ entro de la amplia nómina de los llamados artistas viajeros que llegaron a la República mexicana en la primera mitad del siglo XIx, el francés Petros Pharamond Blanchard ha sido un pintor ignorado hasta ahora por los estudios de historia del arte en México; es un hecho que muy pocas veces se le menciona y casi no se ha presentado su obra en exposiciones dedicadas a este grupo. ${ }^{I}$ Dado que es un artista menor en Francia, a Blanchard se le ha rescatado en museos de España donde se ha mostrado su trabajo de manera individual, pero no así en México, ${ }^{2}$ pues sólo en algunas ocasiones he podido encontrar un cuadro de este artista en exhibiciones, como la que organizó el Museo de San Carlos sobre el estado de Veracruz en 1989, y en cuyo

I. Véase el catálogo de la exposición Viajeros europeos del siglo XIX en México, coord. Pablo Diener Ojeda (México: Fomento Cultural Banamex-Comisión Europea, 1996). En este catálogo no se encuentra la menor mención al artista de Lyon. Tampoco lo menciona Stacie Widdifield en su artículo "El impulso de Humboldt y la mirada extranjera sobre México", en Hacia otra historia del arte en México. De la estructuración colonial a la exigencia nacional (I780-1860), coord. Esther Acevedo, t. I (México: Consejo Nacional para la Cultura y las Artes, 200I), 257-27I.

2. Paul Guinard, "Pharamond Blanchard, cronista de la 'Villa y Corte', Goya, núm. 46 (enero-febrero, 1962): 280-288. En este artículo se señala la importante exposición individual sobre Blanchard alrededor de 1960 en el Museo Romántico de Madrid. 
catálogo se refieren algunas líneas a su vida y obra. ${ }^{3}$ Por consiguiente, también ha estado ausente en las principales listas de pintores y litógrafos en las que se incluye a personalidades como Linati, Gualdi, Rugendas, Nebel, Egerton o sus compatriotas franceses Pingret, el barón de Courcy o el barón de Gros, por mencionar sólo a algunos. ${ }^{4}$ Lo ubico en esta categoría ya que es un pintor extranjero, que realizó un viaje a nuestro país e hizo un trabajo artístico sobre temas mexicanos. Considerarlo un pintor expedicionario, como algunos han sugerido, es una subcategoría aceptable aunque no amplia, pues no permite verlo en relación con todo este grupo de artistas. Si de manera sorprendente su trabajo como pintor se ha omitido en la historiografía especializada, este olvido también ha alcanzado su faceta como escritor ya que su nombre tampoco aparece en la extensa revisión de extranjeros que dejaron testimonios o impresiones escritas del país, pese a que publicó en I839 un voluminoso libro que lleva por título, San Juan de Ulúa: ou relation de l'expedition française au Mexique sous les ordres de M. Le Comte Amiral Baudin; por MM. P. Blanchard et A. Dauzats. Suivi des notes et documents et d'un aperçu général sur l'état actuel du Texas par M. E. Maissin, lieutenant de vaisseau, aide-de-camp de l'amiral Baudin. 5 Es una lástima que este libro, con interesantes viñetas, no se haya traducido aún, como otros del género escritos por autores como Ward, Madame Calderón de

3. Elisa García Barragán, Catálogo de exposición, Veracruz, los colores del sol. Paisaje, retrato y costumbrismo (México: Museo de San Carlos, 1989).

4. Ya que durante mucho tiempo se desconocía la existencia de Blanchard, Fausto Ramírez Rojas, destacado investigador, no lo menciona en su importante recuento sobre artistas extranjeros, véase "La visión de la América tropical: los artistas viajeros", en Historia del arte mexicano: arte de la afirmación nacional (México: Secretaría de Educación Pública/Instituto Nacional de Bellas Artes/Salvat, 198I), núm. 68. Asimismo, Manuel Romero de Terreros tampoco lo mencionó en su trabajo pionero, "México visto por artistas extranjeros del siglo XIX", Anales del Instituto de Investigaciones Estéticas VII, núm. 28 (1959): 33-46. Sorprendentemente Chantal Cramaussel en su artículo, "Pintores franceses en México durante la primera mitad del siglo xIx", lo menciona brevemente y lo cataloga más como un litógrafo que como un pintor, véase Chantal Cramaussel y Delia González, eds., Viajeros y migrantes franceses en la América española y portuguesa durante el siglo XIX, t. I (Zamora: El Colegio de Michoacán, 2007), I57-I78.

5. La obra, se aclara, fue Publié par ordre du Roi, sous les auspices de M. Le Baron Tupinier, alors ministre de la Marine. Paris, Chez Gide editeur, rue de Seine, s.-g. 6 bis, I839. Un ejemplar de este libro se encuentra en la Universidad Autónoma del Estado de Nuevo León, el cual por fortuna también se puede consultar en línea. Agradezco a los encargados de la biblioteca las facilidades para obtener una copia. Cabe señalar que el título del libro se encontraba también registrado en la Biblioteca Nacional de la Universidad Nacional Autónoma de México, por lo menos en 2012, aunque este ejemplar no se localizó físicamente. 
la Barca, Stephens, Poinsett, Ruxton, entre muchos más. ${ }^{6} \mathrm{Ni}$ siquiera en la acuciosa revisión que hice de los in volúmenes editados por el gobierno de Veracruz sobre un gran número de viajeros que recorrieron ese estado, encontré la más mínima mención a Blanchard, ${ }^{7}$ pese a que fue justamente esta región la que recorrió y describió con mayor detalle. ${ }^{8}$ Tampoco el trabajo pionero, y ahora poco conocido, de Jorge Silva, Viajeros franceses en México, ${ }^{9}$ lo menciona y sucede lo mismo con otros textos sobre el tema.

Son más bien libros recientes sobre la historia de Veracruz, tanto del estado como del puerto, los que se han ilustrado con obras de Blanchard, y que lo han dado a conocer, si se pudiera decir así, al divulgar su producción; sin embargo, no se detienen en el artista, pues sus piezas sólo acompañan los textos, y no aparecen datos importantes sobre su biografía. Tal es el caso de Veracruz y sus viajeros, ${ }^{10}$ así como el libro coordinado por Guillermo Tovar y de Teresa y Alejandro de Antuńano con un recuento histórico de la ciudad que fue puerta de entrada al país, Veracruz, primer puerto del continente, ambos con abundantes imágenes de los tipos populares representados por el artista galo. ${ }^{\text {II }}$ En contraste, las

6. Muchas de estas publicaciones las realizaron editoriales como la Secretaría de Educación Pública en la década de los setenta o el Consejo Nacional para la Cultura y las Artes en la de los noventa en su colección Mirada Viajera. El Banco de México ha realizado también traducciones de libros como Carl Bartholomeus Heller o William Bullock.

7. Martha Poblett Miranda, comp., Cien viajeros en Veracruz-crónicas y relatos, siglos XVI al XX (Xalapa: Gobierno del Estado de Veracruz, 1992). El volumen en el cual se debería incluir a este artista es el VI, pues toca los años de I836 a I854 y Blanchard estuvo en el país en I838.

8. Sobra decir que tampoco se encuentra en los cuatro tomos escritos por José Iturriaga de la Fuente con una miscelánea sobre este mismo tema: Anecdotarios de viajeros extranjeros en México; siglos XVI al XX, 4 t. (México: Fondo de Cultura Económica, 1988).

9. Jorge Silva, Viajeros franceses en México (México: América, 1946). Investigaciones recientes como la de Rodolfo Ramírez Rodríguez también han olvidado a Blanchard, véase "Atisbo historiográfico de la literatura viajera decimonónica en México", Trashumante. Revista Americana de Historia Social, núm. I (2013): II4-I36. Lo mismo que la tesis de este mismo autor: "Una mirada cautivada. La nación mexicana vista por los viajeros extranjeros, I824-1874", tesis de maestría en Historia (México: Universidad Nacional Autónoma de México-Facultad de Filosofía y Letras, 20Io). Algunos libros pueden quedar exentos de esta omisión por no tocar estrictamente los años en que Blanchard estuvo en México como el de José Enrique Covarrubias, Visión extranjera de México, I840-1867 (México: Universidad Nacional Autónoma de México-Instituto de Investigaciones Históricas/Instituto Mora, 1998), sin embargo, es notorio que ni en los antecedentes se consideró al artista francés.

Io. Veracruz y sus viajeros (México: Banobras/Gobierno del Estado de Veracruz-Instituto Veracruzano de Cultura, 200I).

II. Veracruz, primer puerto del continente (México: ICA/Fundación Miguel Alemán, I996), con textos 
publicaciones europeas que tratan asuntos sobre México son las que han tenido un mayor interés en proporcionar referencias más puntuales del artista y su obra, tal es el caso del libro Huasteca, con textos de Anne Carion. ${ }^{\mathrm{I2}}$

¿A qué se debe este olvido? Aventuro varias hipótesis, aunque de principio descarto que obedezca a una mala calidad de su obra. Otros artistas extranjeros con trabajos no tan destacables han merecido mucha mayor atención, entre ellos el ya mencionado Claudio Linati o Jean-Frédéric de Waldeck, quienes al realizar gran parte de su producción en la técnica litográfica, alcanzaron una mayor difusión; en este sentido Petros Pharamond se acerca más al caso del barón de Courcy, quien también desarrolló trabajos a la acuarela o el crayón, técnicas con menor alcance para un público amplio, y que permaneció desconocido durante mucho tiempo. Otra razón es que una gran parte de la obra de Blanchard sobre tipos y paisajes de Veracruz, de hecho la más abundante, la adquirió un coleccionista particular de México, en la década de los ochenta, y sólo a partir de entonces la dio a conocer al público mexicano, ${ }^{13}$ por lo que formó parte desde ese momento del grupo de artistas europeos conocidos. Sin embargo, tampoco ésta es una explicación suficiente, toda vez que un personaje como Theubet de Beauchamp (suizo o alemán), descubierto después de Blanchard, ha merecido una edición facsimilar importante. ${ }^{14}$ Creo que una posible causa apunta más al hecho de que su trabajo de escenas de batallas, como son las cuatro pinturas sobre la toma de Veracruz, estuvo en museos de Francia, por lo general sin exhibirse, dado el tema y su formato pequeño, que pareció no interesar a los investigadores franceses, además de estar en la categoría de

de Alejandro de Antuñano Maurer, Guillermo Tovar y de Teresa, Carmen Blázquez Domínguez, entre otros. En este libro se encuentran varias acuarelas de Blanchard, que han divulgado de manera extraordinaria su trabajo. Existen igualmente otros artículos que se ilustran con la obra del artista.

I2. Huasteca ovvero Messico imperiale (Florencia: Franco Maria Ricci, 1999), textos de Paula Kolonitz, Emmanuel Domenech y Anne Carion.

I3. Quiero agradecer a Agustín Cristóbal por permitirme conocer su colección sobre Blanchard, así como su autorización para reproducir y tomar las fotografías que ilustran este artículo. Igualmente al Museo del Estado de Veracruz por las facilidades para llevar a cabo esta investigación lo mismo que al Museo del Castillo de Versalles.

I4. Véase el voluminoso libro: Trajes y vistas de México en la mirada de Theubet de Beauchamp. Trajes civiles y militares y de los pobladores de México entre I8Io y I827, estudio de Sonia Lombardo de Ruiz (México: Instituto Nacional de Antropología e Historia-Consejo Nacional para la Cultura y las Artes/Turner. 2009). El álbum lo descubrió la misma Sonia Lombardo cerca de 2006 en la Real Biblioteca de Madrid, quien se tomó el cuidado de revisar los datos más elementales, aunque si bien escasos, sobre el personaje. 
obras menores, lo cual implicó que los mexicanos tampoco pudieran conocerlas. Resulta lógico que una versión de La toma de la Casa de Arista, expuesta ahora en el museo de Orizaba, nunca se le había atribuido. No obstante, destaco el hecho de que el libro sobre San Juan de Ulúa ha estado, un largo tiempo en bibliotecas mexicanas, pero ha sido por completo ignorado. Por ello, me parece que un posible origen de este olvido, incluso desdén, se deba a que su trabajo está vinculado precisamente a la primera intervención francesa de I838, también conocida como guerra de los Pasteles, y que haya causado durante mucho tiempo cierto rechazo entre el público mexicano. En especial se ha descartado traducir el libro quizá por motivos de índole nacionalista, lo cual ya no se justifica dada la importancia de contar con una visión integral de la Historia. Aunque no tengo pruebas suficientes, resulta un hecho que para algunos autores esta primera intervención es un tema que, a diferencia de la estadounidense de I846-1847 o la segunda francesa de I862-1867, ha interesado muy poco o incluso se ha omitido por completo en algunos recuentos generales. ${ }^{15}$ Desde luego entre otras causas también se encuentra el olvido del que ha sido objeto el arte del siglo xix que, como bien han señalado autores como Fausto Ramírez y Angélica Velázquez, se debe a que hasta bien entrado el siglo xx se privilegió el muralismo mexicano y otras corrientes artísticas como parte de un discurso nacionalista con claras intenciones oficiales. Fue hasta la década de los ochenta cuando, por diversos motivos, se agotó ese discurso y se dio una revaloración en el mercado del arte de la producción decimonónica. ${ }^{16}$

No obstante, Petros Pharamond Blanchard conjunta lo que pocas veces ha sucedido entre los viajeros: una labor artística y una interesante narración sobre

I5. Quien señala esta falta de interés por explicar el conflicto de manera cabal y objetiva es Faustino A. Aquino Sánchez, en su libro Intervención francesa I838-I839. La diplomacia mexicana y el imperialismo del librecambio (México: Instituto Nacional de Antropología e Historia, 1997), I7, por cierto uno de los pocos libros que han tocado el tema y que hasta ahora no ha sido superado. Un ejemplo de este desinterés es la enciclopedia Gran Historia de México Ilustrada, coord. Josefina Zoraida Vázquez (México: Planeta/Consejo Nacional para la Cultura y las Artes/Instituto Nacional de Antropología e Historia/ 200I), que en el tomo III, El nacimiento de México 1750-I856 no hace la más mínima mención a este conflicto internacional.

I6. Véase Fausto Ramírez, "En torno al arte del siglo xIX, I850-1980", en VIII Coloquio de Historia del Arte. Los estudios sobre el arte Mexicano. Examen y prospectiva, ed. (México: Universidad Nacional Autónoma de México-Instituto de Investigaciones Estéticas, 1986), I44-I46; Angélica Rocío Velázquez Guadarrama, "La pintura costumbrista en la Escuela Nacional de Bellas Artes, 1849-I899. Representaciones femeninas", tesis de doctorado en Historia del Arte (México: Universidad Nacional Autónoma de México-Facultad de Filosofía y Letras, 2016), 22-23 y 25. 
México. El presente artículo se centra casi exclusivamente en el primer aspecto. Dada la riqueza de su obra, tanto plástica como literaria, daré a conocer otros trabajos en los cuales analizaré a mayor profundidad su libro, y destacaré su visión como narrador europeo de nuestro territorio. Es importante señalar que si bien la invasión francesa al Puerto de Veracruz en 1838 fue el motivo principal de su viaje, por órdenes del rey Luis Felipe de Francia —más adelante contó con el apoyo de su amigo, el artista Adrien Dauzats (I804-I868)—, la intención principal fue supuestamente enriquecer la galería de batallas históricas que el monarca estaba formando en el Palacio de Versalles, además de ilustrar el libro con la narración de la expedición, encargo que desbordó su interés. La ya mencionada serie de tipos populares y escenas costumbristas — alrededor de 50- da cuenta de las actividades populares, las diversiones y los personajes de la época en el puerto jarocho en I 838 y, supongo, la hizo motu propio, sin que mediara ningún encargo. Trabajos, quizás, hechos como un ejercicio artístico secundario, pero ahora con un interesante valor iconográfico y a la altura de los ejecutados por Hegi o Pingret que abordaron el mismo género. De igual manera, considero que los grabados que incluyó en su libro San Juan de Ulúa, merecen por sí solos una mayor atención por su calidad estética, por aportar la visión francesa de la guerra de los Pasteles y la recreación del paisaje mexicano. De hecho, Blanchard realizó con posterioridad grabados que se publicaron en revistas francesas con asuntos sobre México, entre 1862 y 1865, quien aunque no regresó al país, quizá los hizo a partir de los recuerdos del viaje y de los apuntes que había tomado en 1838 .

\section{Esbozo biográfico de un artista}

A diferencia de otros artistas viajeros, de los que no se tienen los datos más elementales o apenas se han empezado a documentar realmente, la biografía de Blanchard se conoce de manera detallada gracias al investigador Paul Guinard, quien rescató su trayectoria tanto en España como en Francia, países donde vivió más tiempo. Por ironías del destino Petros Pharamond Blanchard nació y murió justo en los mismos años de otro afamado pintor, especializado en retratos de miembros de la realeza y nobles de las cortes europeas, el alemán Franz Xaver Winterhalter, es decir, de I805 a 1873. Se sabe por los registros que encontró Guinard que Henri-Léon-Petros-Pharamond Blanchard, su nombre completo, nació el 27 de febrero de I805 (en ese entonces el 9 ventoso del año 
XIII) en el barrio de La Guillotière, de la ciudad de Lyon, fue hijo del pintor Jean-Baptiste Blanchard y de Elizabeth Dupont. ${ }^{17}$ El origen de sus primeros nombres se debe a motivos familiares, pero el último y el más usado, el de Pharamond —el cual a Guinard le parece rutilante y romántico—, es el del primer rey en la Edad Media de los francos, antepasados de los merovingios, y significa "el protector de la tribu o del país" nombre envuelto en la leyenda y el mito que el escritor Chateaubriand utilizará después en su prosa épica Les Martyrs. ${ }^{18}$ Sin duda, singular.

Guinard destaca también, aunque no está del todo seguro, que Blanchard provenía de una familia de pintores especializados en la decoración de teatros; piensa que el abuelo de este personaje fue Jean Blanchard, fallecido en 1804 en Lyon, y uno de sus tíos, Henri Blanchard (I787-I858), ambos procedentes de Burdeos, ya que esta profesión los obligaba a cambiar con frecuencia de residencia dependiendo del trabajo en las compañías teatrales. Su biógrafo se pregunta si este común origen bordelés lo acercaría después a Dauzats nacido en dicha ciudad. ${ }^{19}$ En todo caso, tiene mayor certeza respecto de que la familia se mudó posteriormente a París donde el padre formó, junto con otros dos pintores, Mathis y Desroches, el trío más reconocido de los decoradores habituales del teatro italiano. Y aunque no logra comprobarlo, pues las fuentes de archivo que consultó no lo corroboran, está casi seguro de que a Pharamond lo inscribieron en la Escuela de Bellas Artes de París, el i6 de septiembre de i819, es decir, cuando era un adolescente de I4 años, edad muy común para ingresar a las academias. ${ }^{20}$ Son estas mismas fuentes las que señalan que el joven Petros Pharamond fue discípulo del pintor Antoine-Jean barón de Gros (I77I-I835),

17. Paul Guinard, Dauzats et Blanchard peintres de l'Espagne romantique (París: Presses Universitaires de France, 1967), 83, datos tomados de los archivos municipales de Lyon. En este trabajo Guinard, quien fue profesor de la Facultad de Letras de Toulouse, realiza la biografía de los dos artistas y vincula sus trayectorias, ya que ambos estuvieron en Espańa donde realizaron importantes trabajos, además de haber sido amigos. De hecho, mucha de la información es sobre Adrien Dauzats de quien encontró más fuentes, a pesar de lo cual profundizó sobre la información que ya había publicado Blanchard antes en la revista Goya, citada con anterioridad. Agradezco la localización y la compra de este libro a Nadia Prevost Urquidi en 2009.

18. Guinard, Dauzats et Blanchard, 83-84.

19. Guinard, Dauzats et Blanchard, 84.

20. Guinard, Dauzats et Blanchard, 84. Guinard no encontró registro de Pharamond en los archivos de la Escuela, aunque su fuente es el diccionario de Émile Bellier de la Chavigniere y Louis Auvray, Dictionnarie général des Artistes de l'École française, t. I (Renouard, I868-1882), 97, pero reconoce que las fuentes del diccionario son desconocidas. 
destacado por sus pinturas históricas de Napoleón y padre de Jean Baptiste Louis Gros (1793-1870), quien estuvo en México en I832 como diplomático, además de realizar varios paisajes. Asimismo recibió la enseñanza de un pintor oscuro y hoy casi olvidado, Charles Abraham Chasselat (I782-I843), especializado en temas históricos y religiosos. ${ }^{2 \mathrm{I}}$

En todo caso Guinard sospecha, con justa razón, que combinó el aprendizaje con las enseñanzas de su propio padre como decorador de teatros, pues trabajó en un diorama de Bouton y Daguerre, y también en una vista de Jerusalén hecha en i822 la cual le dio cierta fama. ${ }^{22}$ En la Escuela de Bellas Artes permaneció alrededor de cuatro años donde aprendió litografía, oficio que le permitió emprender un viaje crucial a Madrid, contratado como parte del grupo de artistas extranjeros que fueron a España a hacer una serie de estampas litográficas para una obra monumental: Voyages pittoresques et romantiques (viajes pintorescos y románticos), muy de moda entonces y dirigida por el barón de Isidore Justin Severine Taylor (1789-1879), quien también fue el editor. Guinard calcula la fecha de este encuentro en agosto de I823, cuando también conoce a su gran amigo Dauzats, quien había llegado a trabajar como decorador en el teatro italiano de París, y a otros artistas franceses, que forman parte del equipo. ${ }^{23}$ ¿Por qué elegir a Petros Pharamond Blanchard? Es un misterio que Guinard tampoco resuelve, pero con seguridad Taylor notó algún talento en el joven artista para contratarlo.

Este viaje a España será decisivo, pues a la par de realizar paisajes y litografías, publicados por la casa de Constans, cuando regresa a París en I824, dicha estancia también le servirá para conocer al pintor José de Madrazo, designado por estas fechas como director de la Academia de Bellas Artes de San Fernando e igualmente del Museo del Prado por el rey Fernando VII. El pintor español hace regresar a Blanchard en I825, junto con su compatriota Jollivet y el belga Decraene para poner en marcha su gran obra: La real colección litográfica que busca reproducir en láminas litográficas las principales obras del Museo del Prado, ${ }^{24}$ y dar así a conocer a un público más amplio las colecciones del famoso Museo, lo que dio un nuevo auge a la carrera de este artista. Pero después de ocho láminas, en las primeras entregas, entre I826 y I827,

2I. Guinard, Dauzats et Blanchard.

22. Este dato lo toma Guinard de Jules Claretie quien lo publica en el periódico L'Illustration, en $1873,405-406$. Fecha seguramente de cuando murió nuestro artista.

23. Guinard, Dauzats et Blanchard, 84 y 448.

24. Guinard, "Pharamond Blanchard, cronista", 283. 
cesó su colaboración de manera intempestiva. Aunque Blanchard de hecho, continuó en España e hizo varias ilustraciones litográficas para la efímera revista de Madrazo: El Artista. Igualmente logró una clientela como acuarelista y retratista, lo cual explica su permanencia en el país ibérico; además, según Guinard, obtuvo la protección del infante Francisco de Paula y Borbón (1794-1865), quien era pintor, académico de honor en San Fernando y mecenas de artistas, entre ellos Blanchard. El apoyo del príncipe será importante; se sabe que en un álbum de su colección se encontraron cinco acuarelas de Petros Pharamond que después pasaron a la Biblioteca Nacional, entre ellas dos encantadoras vistas de Aranjuez. ${ }^{25}$

Dadas tan halagüeñas perspectivas, decidió establecerse en España por tiempo indefinido, circunstancia que explica por qué ejecuta los retratos del mismo infante Francisco de Paula y su esposa, la infanta Luisa Carlota, cuando van de cacería en I832, montados a caballo al parecer a todo galope, seguidos de un gran séquito de amigos, sirvientes y perros de caza. Por ello su integración en el mundo madrileño es total, incluso hablaba corrientemente el español pues, según señalamientos en una carta de su amigo Dauzats, menciona que: "contando una anécdota en francés [...] cita la frase final en castellano". ${ }^{26}$ Otra prueba de esta integración y de los apoyos que encuentra en España es que mandó traer a sus padres; hay indicios de que Jean-Baptiste Blanchard estuvo en Madrid en I830, ya que en ese año pinta el nuevo plafón del teatro del príncipe. De hecho, el padre de Blanchard continuó durante varios años en la capital espańola como decorador de los teatros municipales, Cruz y Príncipe, e incluso formó alumnos antes de regresar a París, donde muere en $1844 \cdot{ }^{27}$

Por su parte, Petros Pharamond siguió cosechando éxitos pues realizó litografías con temas españoles que luego se publicaron en Francia y expuso en el salón parisino de I834, donde mandó el cuadro que lleva por título Corrida de toros en un pueblo español, el cual obtuvo cierto reconocimiento y, según Guinard, le valió varios encargos en diversos círculos de aficionados taurinos. Prueba de ello es que un mecenas ruso que vivía en París, el joven, fastuoso y caprichoso conde Demidoff — después príncipe de San Donato-, lo invitó a su finca y le encargó una nueva colección de dibujos de corridas de toros. Sobre este mismo tema exhibió otro cuadro en I836, también en París, que sin duda le servirá como

25. Guinard, "Pharamond".

26. Guinard, "Pharamond", 284.

27. Guinard, "Pharamond". 
antecedente para los trabajos ejecutados en México sobre escenas costumbristas y tipos, hechos tanto a la acuarela como en litografía, donde destacan las plazas taurinas como telón de fondo para los toreros y los picadores que se enfrentán a los bravos animales en diferentes poses. En otras estampas se encuentran los toreros tras bastidores, fumando, bebiendo o rezando ante la Virgen antes de entrar al ruedo. Por estas fechas pinta un cuadro que perteneció al duque de Montpensier, Los pobres de San Bernardino calentándose al sol, el cual Guinard no duda en calificar como "el canto del cisne o el testamento de su época madrileña”; en él presenta a los desheredados del pueblo, entre ellos unos niños huérfanos, una negra y un viejo hidalgo alineados con su triste dignidad delante de un muro lechoso, iluminado por un sol enfermo, resulto en una gama de negros, grises y ocres. ${ }^{28}$ Obras todas impregnadas de un "velazquismo auténtico", muy en boga entre los costumbristas menores de la época, pero que, a mi parecer, muestran ya la personalidad del artista en el uso del color, la luz y ciertos tonos que destacan lo que quiere representar, además de una buena composición aprendida en la academia y que refleja de alguna manera la búsqueda del exotismo en tierras ibéricas; sin duda el autor estaba consciente de que gran parte de estos trabajos eran para un público francés. No se puede olvidar que el momento en que se hicieron estos cuadros, al igual que las vistas de España, está impregnado ya de cierto romanticismo característico del gusto de la época.

Resulta natural que a finales de I835, cuando le encarga el rey Luis Felipe al barón de Taylor construir una galería de cuadros españoles para el Louvre, éste regrese a España para dicho fin y recurra nuevamente a Petros Pharamond Blanchard y a Adrián Dauzats, como artistas expertos e intérpretes. ${ }^{29}$ La elección no es gratuita, Guinard reconoce que el primero era el artista francés "grande o pequeño" que conocía mejor Madrid por dentro. Además de la obra que se ha mencionado, tenía en su haber otras series madrileñas referentes a fiestas reales: la de junio de I833, llamada La jura de la infanta Isabel, que Fernando VII precipitó ansiosamente para asegurar el trono a su hija, conformada por cinco litografías con las ceremonias oficiales en San Jerónimo el Real, y las corridas de toros de la misma fiesta realizadas en la Plaza Mayor y en la vieja Plaza que estaba en la puerta de Alcalá, ${ }^{30}$ lo cual habla del reconocimiento a su labor en este género.

28. Guinard, "Pharamond", 285-286.

29. Guinard, "Pharamond".

30. Guinard, "Pharamond”, 286-287. Posteriormente, Blanchard realizará otra serie en I846, sobre las dobles bodas reales de la reina Isabel con Francisco de Asís y la de la infanta Luisa Fernanda con Antonio de Orleans, duque de Montpensier. 
En I836 acompañó al barón de Taylor por el sur de Espańa; viaje que, alternó con su trabajo en Madrid, lugar donde vivía en la calle de Jardines 24. Después Guinard le pierde la pista, aunque sabe que estuvo en Cádiz y se trasladó a Marruecos alrededor de I837, ya que expuso en el salón de I838 una vista de Tánger. A partir de entonces no se tienen noticias de él hasta el momento en que lo contratan para la expedición a México, a finales de 1838, como parte de la comitiva del príncipe Francisco Fernando de Orleans, príncipe de Joinville almirante de la marina francesa y sólo unos meses antes de que su amigo Dauzats acompañara a Fernando Felipe, duque de Orleans, a Argelia a otra expedición similar. ${ }^{3 \mathrm{I}}$ Guinard sospecha que los trabajos que había realizado con Taylor en España, e incluso alguna recomendación del mismo barón al rey, influyeron en la decisión para escogerlo como pintor oficial de esta expedición. Pero, sin duda, el hecho de hablar y conocer muy bien el idioma español contribuyó a su elección, pues el viaje representaba una promoción muy importante para cualquier artista, de entre los muchos que abundaban en Francia, pese a ser un trabajo no exento de riesgos y de durar varios meses. Este punto se corrobora pues además de pintor, Blanchard fungirá como traductor en las negociaciones que tuvieron lugar en nuestro país, como adelante se verá.

\section{Petros Pharamond Blanchard en México y la expedición de 1838}

Gracias a las minuciosas investigaciones de Guinard y al libro San Juan de Ulúa, se sabe que Petros Pharamond Blanchard recibió, como parte de los arreglos de su contrato, una gratificación anticipada de 2,000 francos junto con un reloj de oro. Quedó bajo las órdenes del príncipe Joinville y del almirante Charles Baudin y se embarcó en el puerto de Brest el 3I de agosto en la corbeta $\mathrm{La}$ Créole. ${ }^{32}$ En ella viajaba también el hijo del rey, para reforzar la escuadra francesa que se encontraba en las costas del Golfo, desde marzo de ese año para exigir al gobierno del presidente Anastasio Bustamante el pago de una indemnización exagerada para los súbditos franceses que supuestamente habían sufrido ataques y destrucción en sus propiedades, sobre todo en la Ciudad de México. Como es bien sabido, todo ello era un pretexto que respondería a intereses más

3I. Ambos eran hijos del rey de Francia, véase Guinard, Dauzats et Blanchard, peintres, 86.

32. Guinard, "Pharamond", 87. A su vez Baudin viajaba en la fragata Nereida, datos que menciona Blanchard, en su obra San Juan de Ulúa, 2-4. 
amplios pues no se había concretado un tratado definitivo de amistad y comercio entre el gobierno mexicano y el francés después de reconocer la Independencia en I830; en el fondo, la expedición sólo buscaba un trato privilegiado en el aspecto comercial. ${ }^{33}$ Las gestiones para conseguir ese beneficio, habían empezado desde 1834 y por diversas circunstancias no habían sido ratificadas. ${ }^{34}$ Por este motivo Francia hizo reclamaciones al gobierno mexicano en I837, con el argumento de los agravios sufridos en propiedades de franceses, lo cual tensó las relaciones. Fue el I7 de junio de ese año cuando el ministro del Exterior, Luis G. Cuevas, dirigió una carta al barón Antoine-Louis Deffaudis, a la sazón representante de Francia en México, acusándolo de haber escrito una misiva insultante en contra de la dignidad nacional. Deffaudis, lejos de retractarse, defendió su postura en favor de las reclamaciones y ante el choque de ambos políticos, el I6 de enero de I838, pidió sus pasaportes y abandonó la capital..$^{35}$ Las cosas no pararon ahí, pues con apoyo de su gobierno, regresó el 6 de marzo acompañado de una fragata de guerra y cuatro bergantines, al mando del comandante Bazoche para exigir por la fuerza la reparación del daño. ${ }^{36}$ Estas naves fondearon en Antón Lizardo y a los tres días pasaron a la Isla de Sacrificios en Veracruz, amenazaron con invadir territorio mexicano si no se cumplían las condiciones que Deffaudis plasmó en un ultimátum el 2i de marzo a bordo de la fragata L'Herminie, en el cual exigía, entre otras demandas, el pago de 600, ooo pesos que vencía el is de abril. ${ }^{37}$ En dicho documento se incluía, entre otros más, el pago a un pastelero residente en la Ciudad de México, de ahí que se llamara popularmente a este conflicto "guerra de los Pasteles". El gobierno mexicano contestó que el honor nacional no admitía más que la retirada incondicional de los barcos franceses, y al no darse solución alguna, inició el bloqueo al puerto el i6 de abril..$^{38}$ Durante largo tiempo, los navíos permanecieron apostados en costas mexicanas, y privaron al gobierno nacional de los ingresos aduanales además de debilitar al ejército mexicano en el Castillo de

33. Para las razones y los detalles de la guerra, véase Aquino Sánchez, Intervención francesa.

34. Josefina Zoraida Vázquez, "La guerra de los Pasteles", en Historia de México, t. II (México: Salvat Mexicana de Ediciones, 1986), 1777.

35. Zoraida Vázquez, "La guerra de los Pasteles".

36. Véase Aquino, Intervención francesa, I42. Este autor señala el nombre de las naves que llegan primero como son L'Herminie de 60 cańones y los cuatro bergantines, el Laurier, el Alcibiade, el Eclipse y el Dunois, pues algunos autores no dan número de soldados ni nombres precisos.

37. Vázquez, "La guerra de los Pasteles", I780.

38. Vázquez, "La guerra de los Pasteles”, I780-I782. 
San Juan de Ulúa, ya de por sí agotado por la reciente guerra con Texas, la falta de armas, alimentos y, en general, de recursos. Fue en este impasse cuando llegaron los refuerzos el 26 de octubre con el príncipe de Jonville y Baudin a la cabeza, para sumar más de 20 buques y casi 4,00o hombres. ${ }^{39}$ De hecho Blanchard señala en su libro que fue días antes cuando la nueva escuadra en la cual venía avistó las naves francesas después de haber pasado por Cuba:

El i8 (octubre) en la mañana, el marinero en vigía señaló dos navíos de guerra a Sotavento, poco tiempo después distinguimos dos fragatas, y en el momento que las banderas fueron izadas, reconocimos a La Herminia y La Ifigenia, que hacían bloqueo en las costas de México; Herminia, fragata de 60 cańones, bajo las órdenes del capitán Bazoche, comandante de la estación del Golfo de México; Ifigenia, fragata de la misma fuerza, comandada por el capitán Parseval. Tenía en Ifigenia, amigos muy queridos que festejaba el volver a verlos. Noticias tristes iban a afligir mi corazón: debía ver las tumbas de la mayoría de los que ahora podía abrazar. Vimos de pronto, mucho antes de ser vistos, dos fragatas; se determinó que estábamos en dirección con ellas, justamente bajo el sol, su resplandor impedía ver un punto tan insignificante como un navío, o por tan grande que fuese sobre la superficie inmensa del mar; eso fue la causa de que ellas nos ganaron mucha ventaja y que hicimos mucho tiempo antes de poder alcanzarlas. Cuando estuvimos a poca distancia, La Herminia saludó a la bandera del almirante Baudin con siete golpes de cañón.

No pude evitar el sentimiento de tristeza viendo al venerable comandante Bazoche; hacía un año que lo había encontrado en Cádiz en la Herminia, pero las preocupaciones, y (esas mismas) tristezas le habían dejado profunda huella en su rostro franco y abierto. ${ }^{40}$

A Deffaudis lo sustituyó de inmediato Baudin, quien el 27 de octubre pidió

39. Las primeras fuerzas francesas que iniciaron el bloqueo desde luego no se libraron de sufrir bajas, no tanto por entrar en algún combate sino por la falta de agua y comida, combinada con el clima de la costa que causó la muerte de varios marineros por la fiebre amarilla y escorbuto. Véase Aquino, Intervención francesa, I85. Por otro lado la cifra total de los hombres y los barcos no es precisa en algunos autores, como sucede con Vázquez, "La guerra de los Pasteles", i78I en cambio Aquino Sánchez, Intervención francesa, 187, proporciona el número preciso de los barcos y marineros que se sumaron además de los primeros y los que venían de Francia, algunos de los cuales se habían integrado desde las Antillas. Estos datos también los cita Blanchard en su libro.

40. Adrián Dauzats y Petros Pharamond Blanchard, San Juan de Ulúa: ou relation de L'expedition française au Mexique sous les ordres de M. Le Comte Amiral Baudin; por MM. P. Blanchard et A. Dauzats. Suivi des notes et documents et d'un aperçu général sur l'état actuel du Texas par M. E. Maissin, lieutenant de vaisseau, aide-de-camp de l'amiral Baudin. Publié par ordre du Roi, sous les 
permiso al general Manuel Rincón, jefe de la plaza, que la defendía desde el castillo de San Juan de Ulúa, para que uno de sus oficiales, el capitán Le Ray, desembarcara con la intención de entrar en contacto con el ministro Luis G. Cuevas, en la Ciudad de México e iniciaran las negociaciones para un arreglo todavía pacífico al conflicto. De hecho, Baudin se dirigió posteriormente a la ciudad de Jalapa donde mantuvo una conferencia el i6 de noviembre con el mismo Cuevas. En estos arreglos la participación de Petros Pharamond Blanchard jugó un papel importante; acompańó a los dos generales franceses y a un oficial mexicano, Calixto Zaragoza, y fungió como intérprete en los arreglos diplomáticos, asunto que él mismo narra en su libro. ${ }^{4 \mathrm{~S}} \mathrm{Si}$ bien no se encontró una solución al conflicto, fue prácticamente un mes el tiempo que tuvo el artista, primero para conocer el puerto y pintar a su gente, y luego para recorrer varias regiones del país, camino a la Ciudad de México, tanto para describirla con minuciosidad como para realizar algunos lienzos, mismos que continuó a su regreso. Lo más probable es que para los de las batallas tomara apuntes y luego los terminara en Francia, pero es de notar que, tomando en cuenta este escaso periodo, ejecutara asimismo un trabajo muy prolífico en el género costumbrista. Con el riesgo de no seguir un orden cronológico, sino de partir de los géneros de sus trabajos, empezaré por los cuadros de guerra.

\section{Pintor de batallas}

De los cinco cuadros que realizó Blanchard en la expedición, cuatro se refieren a la toma y bombardeo de Veracruz y pertenecen hoy a la colección del castillo de Versalles, sin duda, están relacionados entre sí; del quinto se desconoce su paradero. Aunque no existe un orden ni claridad en los títulos, supongo que el primero, dada la cronología de los acontecimientos, es una vista desde la corbeta La Créole, que representa a la escuadra francesa en el momento en que se dispone a atacar las costas de Veracruz, por lo cual la ubicaría en diciembre de 1838 , cuando se rompieron las hostilidades y que lleva por título Combat de la Verá-Cruz (Mexique). Les troupes de débarquement quittent les

auspices de M. Le Baron Tupinier, alors ministre de la Marine (París: Chez Gide editeur, rue de Seine, s.-g. 6 bis, I839), 50 y 5I, trad. del autor.

4I. Para los arreglos del conflicto, véase Aquino, Intervención francesa, 226-248, que hasta ahora es el mejor trabajo al respecto. 
I. Petros Pharamond Blanchard, Combat de la Verá-Cruz (Mexique). Les troupes de débarquement quittent les navires et se dirigent $v$., I843, óleo sobre tela, $48 \times 45 \mathrm{~cm}$. Museo de Versalles, Mv517I.

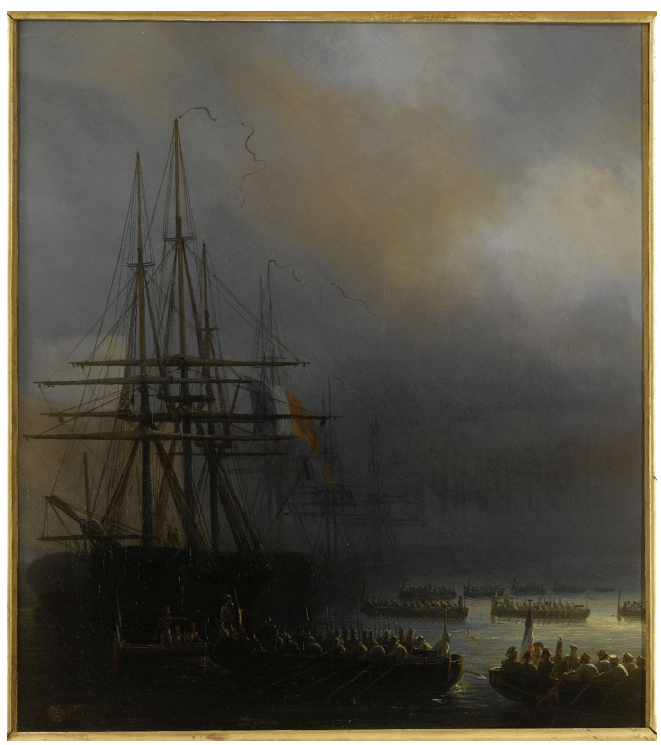

navires et se dirigent $v$. (combate de Veracruz [México]. Las tropas desembarcan y se dirigen a v.), adquirido por el Museo de Versalles por 300 francos el I9 de febrero de ese mismo año (fig. I) ${ }^{42}$ El cuadro de pequeñas dimensiones representa parte de la proa y la cubierta de uno de los barcos en primer plano, con líneas horizontales y verticales que forman los mástiles al parecer tomados en momentos en que la oscuridad de la noche invadía a los buques — ambiente que el artista se dio a la tarea de hacer notar por las tonalidades azules y grises que le imprimió-, mientras de varias lanchas desembarcan los marinos. A diferencia del grabado de otro pintor de batallas, Horacio Vernet (I789-I863), que lleva por título Toma del fuerte de San Juan de Ulúa, en I838, en el cual destaca la figura del príncipe de Joinville desde la proa, con el fondo de un paisaje costero en el que se distingue el bombardeo a la ciudad y el pico de Orizaba, en este cuadro de Blanchard no sobresale ningún personaje (fig. 2). Tales característi-

42. Agradezco a Frédéric Lacalle, conservador a cargo de las pinturas del siglo xix del castillo de Versalles, haberme permitido consultar en junio de 20 II estos cuadros en sus galerías. Hay que seńalar que en el registro de estas obras los títulos se repiten o cambian de nombre, lo que a veces ha creado confusión. El dato de la compra lo menciona Paul Guinard en su libro Dauzats et Blanchard, 453 . 
DOI: http://dx.doi.org/10.22201/iie.18703062e.2018.112.2632



2. Horacio Vernet, Toma del fuerte de San Juan de Ulúa, I839, grabado en metal, $24 \times 33.5 \mathrm{~cm}$. Instituto Veracruzano de la Cultura-Colección Museo de Arte del Estado de Veracruz. Foto: Rafael Doniz, Ivc/063.

cas me han hecho pensar que Vernet no estuvo necesariamente en la expedición y que quizás realizó este único cuadro sobre el tema a partir de las descripciones de los protagonistas o de los mismos grabados de Blanchard, pero superando sin duda, en calidad compositiva al pintor de Lyon..$^{43}$ El que yo supongo es un segundo cuadro lleva por título Les Troupes de débarquement escaladent les

43. Uno de los autores que considera que Vernet estuvo en la expedición, de la cual yo dudo, es Esther Acevedo, tanto para analizar este punto como para apreciar una de las mejores reproducciones del cuadro, véase "De la reconquista a la intervención" en el catálogo de exposición Los pinceles de la Historia. De la patria criolla a la nación mexicana (México: Museo Nacional de Arte/Banamex/Consejo Nacional para la Cultura y las Artes-Instituto Nacional de Bellas Artes, 2000), I89-193. Resulta también interesante que una copia del cuadro de Vernet se encuentra en el palacio imperial de verano, en Petrópolis, del emperador Pedro II de Brasil. Esto sucede ya que el príncipe de Joinville se casó en I843 con Francisca de Braganza, hija de Pedro I de Brasil y seguramente llevó una copia, aunque también es digno de notar que prefiriera el cuadro de Vernet a cualquiera de Blanchard. 
DOI: http://dx.doi.org/10.22201/iie.18703062e.2018.112.2632

ASALTOS AL TRÓPICO

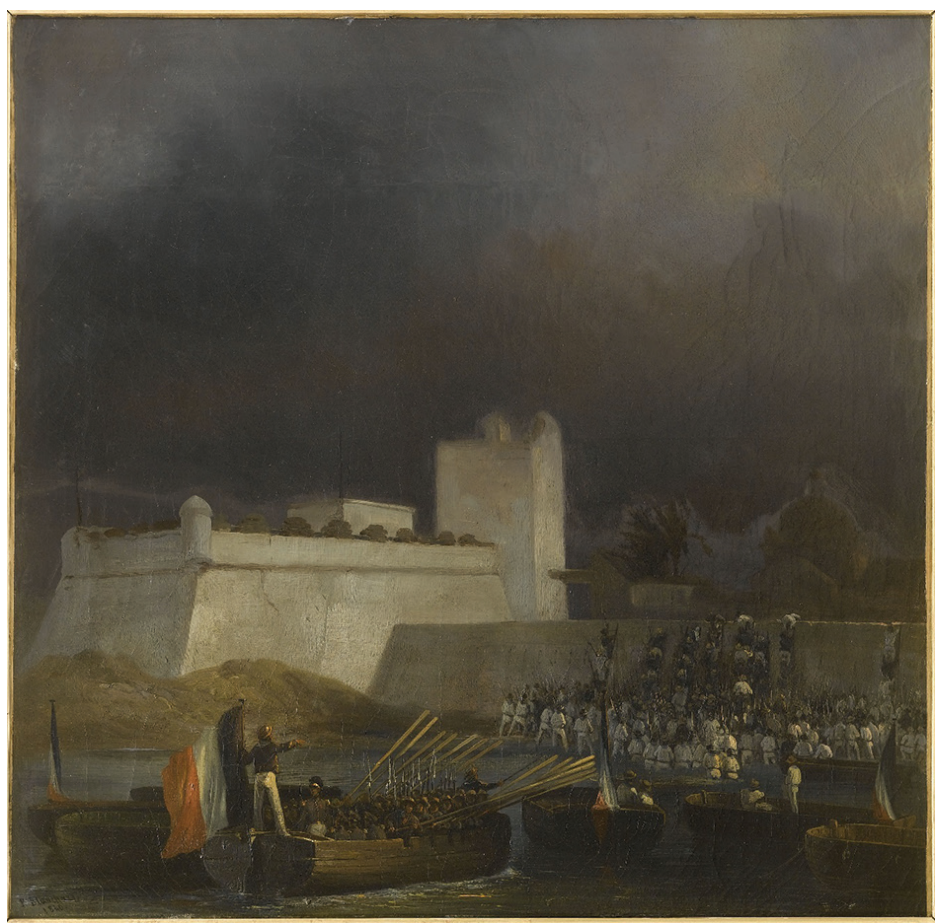

3. Petros Pharamond Blanchard, Les Troupes de débarquement escaladent les remparts du fort sous la conduite du Prince de Joinville (5 décembre), I838, óleo sobre tela, $48 \times 45 \mathrm{~cm}$. Museo de Versalles, Mv5172.

remparts du fort sous la conduite du Prince de Joinville (s décembre) (las tropas de desembarque escalan las murallas del fuerte bajo el mando del príncipe de Joinville [5 de diciembre]) (fig. 3), el cual también podría distinguirse con un título en español, Vista de la toma de San Juan de Ulúa, de las mismas dimensiones que el anterior; según Guinard, se ejecutó en I840 y lo compró el rey en Ioo francos. ${ }^{44}$ En éste destaca igualmente una atmósfera nocturna, tiene como fondo lo que el pintor quiso hacer aparecer como el Castillo de San Juan de Ulúa, con un baluarte de defensa, se ve una torre alta en tonalidades blancas,

44. Guinard, por ejemplo, titula a este cuadro: Coup de main du prince de Joinville sur Vera-Cruz: le débarquement, en Dauzats et Blanchard, lám. XVII, entre las páginas 400 y 401 . La información sobre la compra hecha por el rey se señala en la página 452. 
que desde luego no coincide con las características arquitectónicas reales de este fuerte mexicano, pues faltarían las troneras y una estructura hexagonal. En un primer plano, acercándose a la playa, se encuentra de pie en una lancha que conducen varios marinos, la figura del príncipe de Joinville, sosteniendo la bandera francesa y desde luego en actitud heroica (fig. 4). En el segundo plano aparecen otros soldados escalando un muro lateral, que no existe en realidad, sin que al parecer se note alguna resistencia de fuerzas mexicanas ni se distinga su presencia por ningún lado. Es de notar que la composición se hizo para resaltar el mérito casi exclusivo del hijo de Luis Felipe y que el blanco del castillo y los uniformes de los marineros hacen un contraste muy efectivo con las tonalidades oscuras del cielo por la noche. Digno de notar es que, aunque los registros en el Museo de Versalles tienen el 5 de diciembre como fecha de estos cuadros, en todas las notas, en realidad el ataque al fuerte y el desembarco empezó días antes. El 5 de diciembre fue cuando se tomó el puerto, aunque hubo un intento previo, hecho por ambas partes, de retomar las propuestas y evitar el bombardeo, pero ante nuevos fracasos diplomáticos, el asalto al castillo inició el 27 de noviembre y, valga señalar que, para algunos autores, las privaciones del ejército durante siete meses, con el estado de ánimo completamente pesimista, al considerarse incapaces de defender San Juan de Ulúa y Veracruz, lo que influyó en la derrota. Para Faustino Aquino no hay duda: "la pérdida del fuerte se debió más a la ignorancia de nuestros militares en materia de táctica naval, que a la escasez de sus recursos o al poderío de la escuadra enemiga". ${ }^{5}$ De hecho, San Juan de Ulúa capituló sin resistir por lo menos un asalto ante los primeros bombardeos, por tanto la visión heroica que presenta este lienzo no corresponde del todo con la realidad histórica, que sin duda cumplía con el objetivo de exaltar la participación de Joinville en la supuesta "guerra a muerte" que libró contra los mexicanos.

Un tercer cuadro lleva por título Le prince Joinville conduisant la colonne centrale de débarquement à l'áttaque de la Porte de la Mer lors de la prise de la ville de Vera Cruz, nuit du s décembre o ataque a la Aduana de Veracruz (el príncipe de Joinville conduce al flanco central del desembarque al ataque de la puerta del mar tras la toma de la ciudad de Veracruz) (fig. 5), se sabe por un registro que es de 1843 y de formato también pequeño, se compró para los museos reales de Luis Felipe, junto con el siguiente, el I9 de febrero de ese mismo año. ${ }^{46}$

45. Aquino, Intervención francesa, 250.

46. Paul Guinard, Dauzats et Blanchard peintre, 453. En su libro, el autor titula este cuadro 


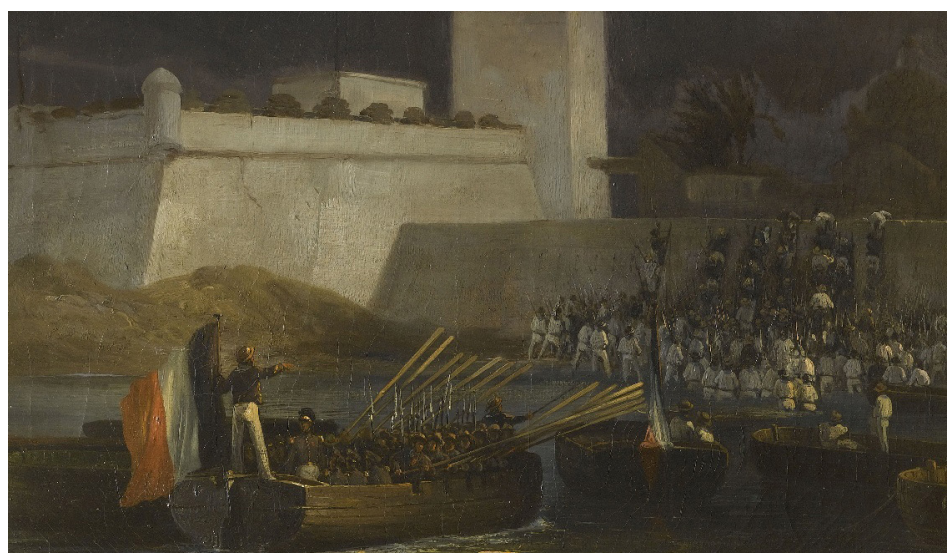

4. Petros Pharamond Blanchard, detalle de Les Troupes de débarquement escaladent les remparts.

Este lienzo se refiere al desembarco que hicieron los franceses esta vez sí a avanzadas horas de la noche del 5 de diciembre para tomar la ciudad de Veracruz después de la capitulación del Castillo de San Juan de Ulúa, y se encontraba en 2009 en una de las oficinas de los Amigos del Museo de Versalles y no en bodega, como los demás. De igual manera es un cuadro que tiene la intención de envolver la atmósfera en un ambiente nocturno, el cielo es de tonos negros, pero la iluminación se concentra en lo que parece ser el muelle y la aduana del puerto, lugar por donde pasaban todos los viajeros y comerciantes que tenían que ser revisados y el cual se distingue por los arcos. De nueva cuenta el protagonista es el príncipe, que parece dirigir a los soldados al ataque, los cuales gracias a la luz que irradia del centro por una explosión, pueden distinguirse con mayor claridad. La acción, de hecho, se inició a las cuatro de la mañana desde los buques anclados frente a Veracruz; con ayuda de lanchas y chalupas salieron las compañías para el desembarco militar, organizado por las tripulaciones de todos los buques de la escuadra francesa. Sin embargo, como había una neblina muy espesa, los soldados no pudieron tocar tierra hasta las 5:30. ${ }^{47}$ En estas acciones participaron capitanes como Parseval de la Ifigenia, Olivier del Cíclo-

como Départ des embarcations au combant de la Vera Cruz (5 décembre I838).

47. Aquino, Intervención francesa, 273. 
DOI: http://dx.doi.org/10.22201/iie.18703062e.2018.112.2632

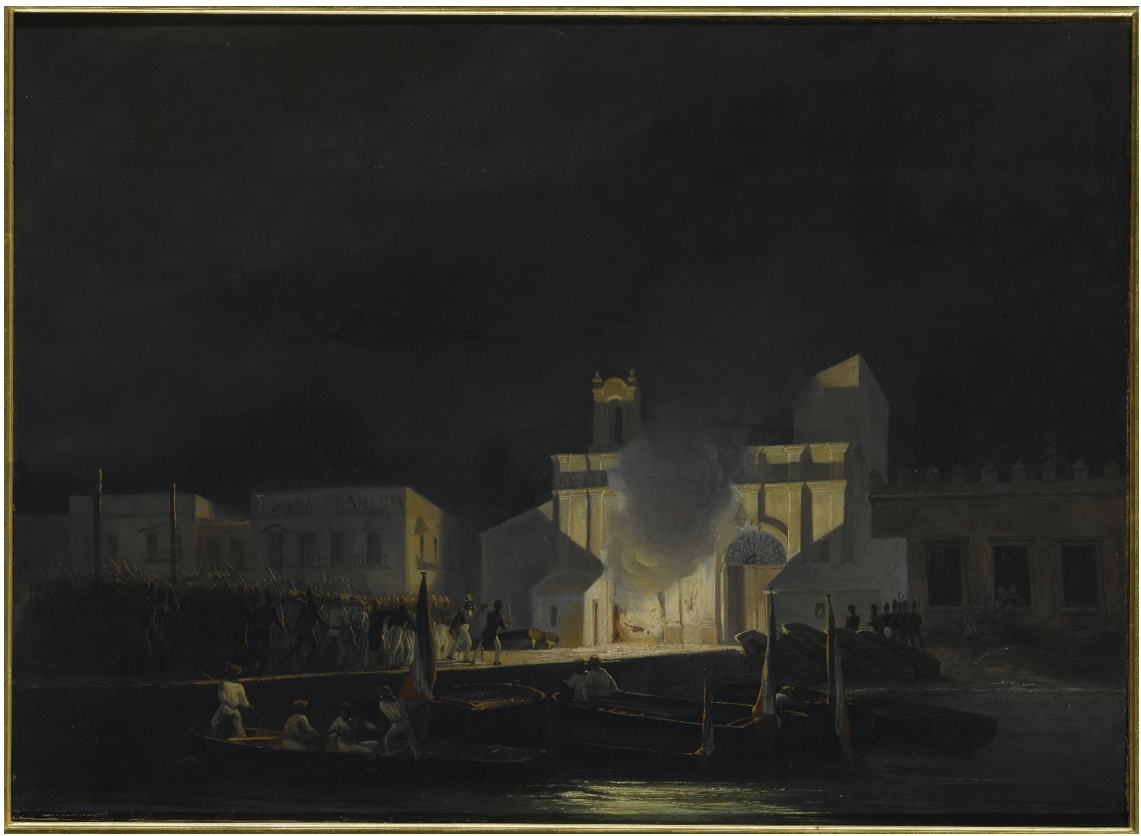

5. Petros Pharamond Blanchard, Le prince Joinville conduisant la colonne centrale de débarquement à l'attaque de la Porte de la Mer lors de la prise de la ville de Vera Cruz, nuit du 5 décembre $o$ ataque a la Aduana de Veracruz, I838, óleo sobre tela, $50 \times 44 \mathrm{~cm}$. Museo de Versalles, MV5567.

pe y S. Georges del Vulcano, quien derribó la Puerta del Rastrillo, mientras el resto tomaba el Fuerte de Santiago y la Puerta de la Merced. El príncipe por su parte, con marinos de $\mathrm{La}$ Créole y coincidiendo con la acción que narra el cuadro, entró por la puerta del muelle que destruyeron por medio de sacos de pólvora para después dirigirse a la casa donde se sabía se hallaba hospedado el general Antonio López de Santa Anna para hacerlo prisionero..$^{8}$

Este último episodio es el que narra el cuarto cuadro en la lista, de hecho el más conocido de esta pequeña serie. Lleva por título Tropas francesas asaltando un convento mexicano, ataque de la Casa de Arista (fig. 6). Al parecer fue el primero que ejecutó Blanchard, pues tiene la fecha de I839; aunque Guinard lo registra en I843, quizá se trata de una copia, repetición por demás lógi- 
ca pues se refiere a la toma de esta casa para atrapar al general Santa Anna y le confiere mayor heroísmo a la acción del príncipe. Otra prueba más de que el lienzo resulta el de mayor importancia de la serie es que también existe un grabado idéntico en el libro escrito por Blanchard y Dauzats, hecha por Chavane (fig. 7), además de una copia que durante mucho tiempo se ha considerado anónima en el Museo de Arte del Estado de Veracruz, en Orizaba; si bien es cierto que Fausto Ramírez tuvo la sospecha de que se trata de un boceto o una réplica del cuadro de Blanchard de Versalles. ${ }^{49}$ La acción tiene como escenario el patio de una casa de dos pisos, rodeado de arcos tanto en el primero como en el segundo nivel, que conduce a los pasillos de la residencia. En el segundo de estos pisos las plantas se desbordan por los balcones de hierro, ornato por demás característico de las casas mexicanas que sorprendía a los extranjeros por el alarde de riqueza de la flora nacional. La composición triangular que se forma con los soldados atacantes en el patio permite, de nueva cuenta, que el príncipe se distinga de entre ellos, al centro de la escena, además de que su uniforme de capitán, el sombrero de copa y un brazo levantado señalando la entrada a los soldados divididos en dos flancos, lo destaquen del resto. Uno de estos soldados está tirado en el piso, al parecer herido al lado de dos oficiales; todos apuntan con sus armas a la parte superior en busca del general escondido lo que refuerza la composición con líneas que señalan al príncipe. La iluminación, que resalta las cabezas de algunos soldados, que portan gorras de marineros, proyecta sombras del lado izquierdo. Sin duda, se podría decir que de los cuatro cuadros es el mejor logrado, tanto por una acertada iluminación, como por el dibujo arquitectónico, la precisión en las figuras y la mencionada composición. No se sabe cómo llegó una copia a México, pero desde luego no es la única pues existe otra más en el Museo de la Marina en París. En este cuadro se prefirió destacar el ataque francés a la casa y no el momento en que se tomaba algún prisionero, ya que es bien sabido que la guardia que se encontraba ahí recibió a los soldados con descargas de fusilería, lo cual fue aprovechado por Santa Anna para huir en medio del tiroteo. "Arista en cambió permaneció en su habitación preguntándose a qué se debía ese tiroteo y el cañonazo que se había escuchado, y que no fue otra cosa que el petardo con que los france-

49. Una de las mejores reproducciones tanto del grabado como de la pintura se encuentra en Fausto Ramírez, "Asedios al Paraíso", Museo de Arte del Estado de Veracruz, catálogo (México: Fomento Cultural Banamex/Gobierno del Estado de Veracruz/TAMsA, 200I), 56, 57 y 58. 
DOI: http://dx.doi.org/10.22201/iie.18703062e.2018.112.2632

236 ARTURO AGUILAR OCHOA

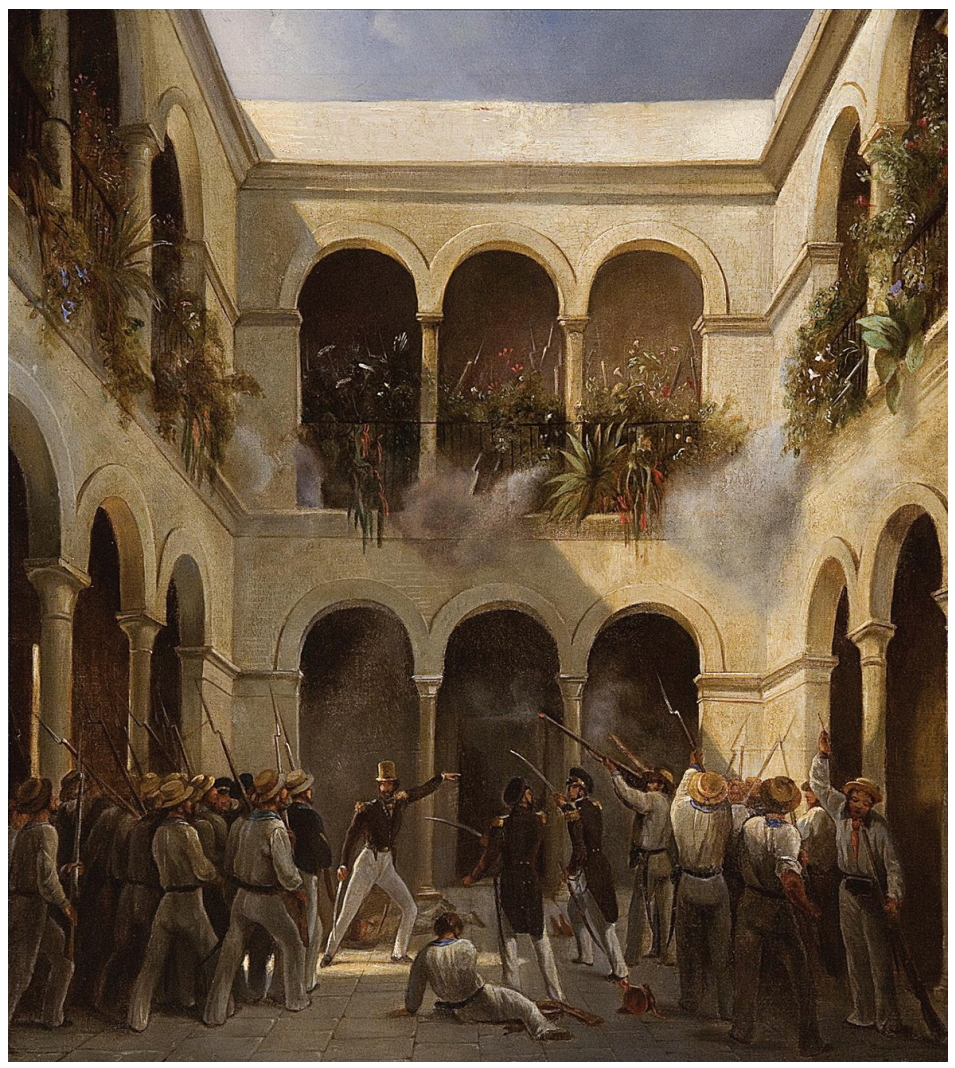

6. Petros Pharamond Blanchard (atribución), Tropas francesas asaltando un convento mexicano, ataque de la Casa de Arista, I839, óleo sobre tela, $50 \times 44 \mathrm{~cm}$. Instituto Veracruzano de la Cultura-Colección Museo de Arte del Estado de Veracruz. Foto: Rafael Doniz, IVc/64.

ses volaron la puerta del muelle" ${ }^{50} \mathrm{El}$ cuadro tampoco consigna el sangriento combate que se libró en los portales del patio y en las escaleras con los soldados mexicanos. Ni la escena del general Mariano Arista hecho prisionero en una de las salas de la casa, quien de hecho "fue presentado al príncipe de Joinville, el cual, poniéndole una pistola en el pecho, le preguntó dónde estaba Santa Anna - a lo que- don Mariano contestó que no lo sabía; y por ello un general francés le dijo que sería fusilado en el acto si no respondía, pero el general

50. Aquino, Intervención francesa, 273. 


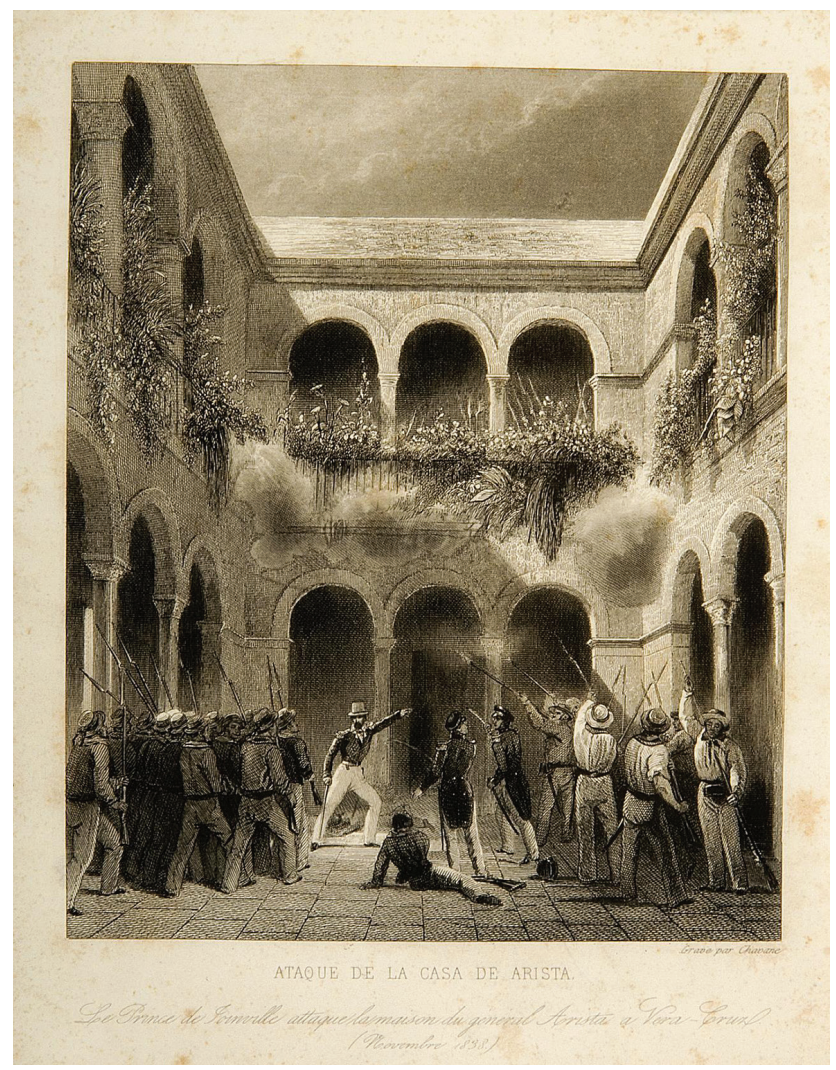

7. Chavane, Asalto a la Casa de Arista, I839, grabado en metal, 2I × I6 $\mathrm{cm}$. Instituto Veracruzano de la Cultura-Colección Museo de Arte del Estado de Veracruz. Foto: Rafael Doniz, Ivc/066.

sabía que tales amenazas eran — por lo común — de rutina para obligar a los prisioneros a hablar". ${ }^{\text {II }}$ Ante tal indiferencia se le condujo ante la presencia de Baudin y, aunque la casa fue registrada, se concluyó que el "pez gordo", que para los franceses representaba Santa Anna, había escapado; éste por cierto, en esos momentos corría por las calles de Veracruz en dirección a los cuarteles, donde se librarían nuevas batallas y perdería una pierna. Todas estas acciones hubieran permitido la representación de escenas de gran alcance, pero desde 
luego esto implicaba, no sólo tiempo, sino un pintor de habilidades más profundas y un formato de mayor tamaño.

El quinto cuadro no se encuentra en la colección de Versalles; hasta ahora se desconoce su paradero y por tanto su título en francés. Se refiere al baile ofrecido por el príncipe de Joinville, en el barco Ifigenia, a las damas de La Habana, a su paso de regreso a Francia, cuando atracó en la isla después de la expedición y el bombardeo a Veracruz. El título que se le podía dar en español es Baile a bordo del Ifigenia, y por datos en el libro de Blanchard es posible fecharlo en enero de 1839. La escena parecería la de un palacio si no se distinguiera el techo improvisado formado por las telas de campaña del salón de baile que se instaló en la cubierta y que luce un gran número de candiles. En un primer plano, de un lado se distinguen las parejas con los oficiales de gran uniforme y la hilera de damas vestidas de gran etiqueta con trajes blancos y vaporosos, que se pierden en un punto de fuga. Del lado derecho, que separa una palmera, se ve el adorno de plantas, gallardetes, espejos y flores, con toques de rojo y verde, que sugieren un ambiente de lujo en el baile, junto con algunas personas sentadas. Al fondo se nota el estrado donde se dispuso un balcón y quizá la mesa para el banquete. La acertada iluminación y una buena composición dotan de calidad al cuadro, pues se distinguen muchos detalles de la escena que representa. Gracias al libro San Juan de Ulúa, que contiene una minuciosa descripción de todo el viaje, se sabe que el i3 de enero Blanchard llegó a La Habana a bordo del barco Lapérouse y ahí se entera del proyecto que había concebido el príncipe, el cual se había adelantado para dar un suntuoso baile a la sociedad habanera a bordo del barco y desperdirse de América. De hecho, según narra "S. A. S. añadió amablemente que confiaba en mí para los arreglos decorativos de la fragata; - que recibí- como un favor y prueba de confianza, que yo habría solicitado si su alteza no hubiera prevenido mi demanda". ${ }^{22}$ En el mismo libro, en el cual se encuentra un grabado casi similar a la pintura, se dice que se emplearon 12 días para los preparativos del baile y los arreglos en el barco, al que concurrieron representantes de Inglaterra, algunos franceses expulsados de México, todos los oficiales apostados en el puerto, además de las más importantes damas y caballeros de La Habana. El baile se ofreció el 28 de enero, fue un derroche de lujo, tanto por el banquete, los adornos mencionados del barco en el que no se omitió ningún gasto y la orquesta que estuvo formada enteramente por músicos negros — la cual se distingue en una alta tarima 
a la derecha- - y cuyo director compuso una contradanza para la ocasión con el alusivo nombre de La Ifigenia en México. ${ }^{53}$ Digno de notar es que mientras realizaba los arreglos del barco, Blanchard tuvo la oportunidad de recorrer la ciudad de La Habana y asistir a la ópera, que en ese entonces tenía como figuras al famoso tenor Galli y a la soprano Madame Albini, quienes habían estado en México, apenas unos años antes. ${ }^{54}$

Se podría suponer que la intención de todos estos cuadros sería adornar la Galería de Batallas, en el Museo de Versalles, pero como he dicho su pequeño tamaño descarta esta posibilidad. Es bueno recordar que el 29 de agosto de I833 Luis Felipe había ordenado a Frédéric Nepveu, su arquitecto en Versalles, empezar la total renovación de la Gran Sala de Jardines, en el primer piso de la estructura central del palacio, 55 para convertirlo de residencia real a un museo histórico para el pueblo; aunque este plan iconográfico inició realmente dos años después, en I835, e iba más allá de incluir los triunfos o "glorias militares francesas" recientes. Cabe advertir que no sólo se pretendía que esos triunfos fueran de su reinado, ya que las imágenes de esta galería estaban inspiradas en sucesos desde la época medieval hasta el tiempo moderno. De hecho, de los siete que tocan el periodo posterior a la Revolución francesa, cinco se dedicaron a los triunfos de un solo hombre: Napoleón Bonaparte, en la llamada Salle du Sacre, numéricamente más abundantes en comparación con los del mismo "rey burgués". ${ }^{6}$ Entre los cuadros en homenaje a Napoleón se encontraba La batalla de Austerlitz, realizado en I8Io por el famoso pintor François Gerard y llevado al palacio en este periodo o los encargados ex profeso por el rey a su pintor favorito, Horacio Vernet, en I836, como La batalla de Jena, La batalla de Friedland y La batalla de Wagram. Por supuesto, para algunos autores detrás de todo ello se escondía una astuta estrategia política diseñada para legitimar su gobierno, al utilizar la pintura histórica como un discurso propagandístico que mandaba entre otros mensajes, situar a Luis Felipe y sus here-

53. Dauzats y Blanchard, San Juan de Ulúa, 4I6 y $4 \mathrm{I} 7$.

54. Dauzats y Blanchard, San Juan de Ulúa.

55. Michael Marriman, Painting Politics for the Louis-Philippe. Art and Ideology in Orlénist France. $1830-1848$ (New Haven y Londres: Yale University Press, 1988), I50. Para el nuevo plan de reestructuración del Palacio, véase Thomas W. Gaeghtgens, Versailles, de la Résidence royale au musée historique: La Galerie des Batailles dans le museé historique de Louis-Phillippe (Amberes: Mercatorfonds, 1984). También Claire Constans, Musée National du Château de Versailles: catalogue des Peintures (París: Editions de la Reunion des Musées Nationaux, 1980).

56. Marriman, Painting Politics, I64-I66. 
deros en la tradición de la política liberal fundada en 1789 por la Revolución francesa. De igual manera la exaltación de los triunfos napoleónicos tiene una función mucho más profunda: detener la oposición bonapartista y republicana contra el régimen orleanista, pues entre otros objetivos, conciliaba la figura del emperador, alejaba a la monarquía de Julio del odiado absolutismo borbónico de la época precedente de la Restauración, y lo conectaba con los supuestos principios constitucionales y heroicos de la época napoleónica. ${ }^{57}$ La mejor prueba de todo ello es que, por gestiones del mismo Luis Felipe, se traen las cenizas de Napoleón en 1840 de la isla de Santa Helena, para depositarlas en Los Inválidos, de París, encomienda que por cierto se le encarga al príncipe de Joinville. En resumen no era necesario en este plan de la manipulación del pasado incluir los triunfos militares del momento, los cuales de por sí eran escasos.

Estas circunstancias explican porqué no se mandó al mejor pintor del momento, como era Horacio Vernet, a una expedición, se podría decir menor, como era la de México y se prefirió a Blanchard y Dauzats, a los cuales se les encomendó primordialmente ilustrar con abundantes grabados el libro de San Juan de Ulúa que también cumplía una propaganda política. Aunque Guinard no lo aclara, supongo que de los pequeños cuadros de batallas hechos por Blanchard y presentados en la Academia, quizá derivaron estos grabados. En todo caso fueron obras secundarias, quizá le servían como referencias para ser utilizadas, sólo en caso necesario, en un proyecto pictórico más ambicioso como base de cuadros de mayores dimensiones, lo que desde luego no se concretó. No hay noticias de que Blanchard hiciera otros trabajos como pintor de batallas, de ahí que no se aborde más este aspecto.

\section{Cuadros de costumbres y tipos populares}

Si el amplio proyecto del rey Luis Felipe en su galería de batallas en el Palacio de Versalles impidió a Blanchard brillar en este escenario, en cambio le dio la oportunidad para desarrollar una de las mejores series costumbristas y de tipos populares mexicanos que se hicieron en el siglo xix. Este conjunto, como he dicho, se compone de aproximadamente 50 obras casi todas a la acuarela que van de simples apuntes a un lienzo al óleo de mayores dimensiones, donde es notorio un mayor cuidado en la ejecución. Valga señalar que la preferencia en 
estos cuadros por los tipos y paisajes tanto del puerto de Veracruz como de lugares cercanos se debe, sin duda, a que en esta zona el artista estuvo más tiempo y quizás en el puerto jarocho Blanchard tuvo una mayor oportunidad para explayarse en sus dotes artísticas que en cualquier otra región del país, incluidas las ciudades de México o Puebla las cuales también conoció. Por ello cito la impresión que se hizo del puerto cuando lo avistó por primera vez desde la Isla de Sacrificios, y señaló, como muchos otros viajeros, su malsano clima:

una larga línea de dunas de arena blanquecina domina tristemente la playa y da un aspecto de aridez. El paisaje es cortado por las colinas cubiertas de alguna vegetación, pero entre las dunas y las colinas se encuentran los pantanos que al no tener medios de desecho exhalan miasmas de aguas pútridas que invaden todo el ambiente.

La fiebre amarilla de estos pantanos es el terror para el extranjero, ella defiende el territorio mejor que lo podría hacer cualquier otra arma. Contra ella la bravura es impotente. La Villa de Veracruz tiene sus casas y sus iglesias pintadas de colores varios, sus murallas blancas parecen como perdidas en la arena que la rodean por todos lados; a 800 metros hacia el N. N. E. sobre un arrecife, está emplazado el fuerte de San Juan de Ulúa blanco como la villa que defiende y que domina con su artillería..$^{8}$

No en vano la vińeta que ilustra el capítulo de su libro dedicado al puerto tiene la imagen de las tumbas de los soldados franceses enterrados en la Isla de Sacrificios, que sucumbieron a la fiebre antes de entrar en algún combate, razón por la cual la llama tierra de batallas, pero también "de sollozos y diabólica, por la muerte que se encontró aquî”. Pese a ello, Blanchard hizo una vista más amable del puerto, a la acuarela, desde la playa hacia San Juan de Ulúa, en la que destacan las olas del mar que rodean el fuerte; pero los tipos jarochos son los

58. "[...] une longue ligne de dunes de sable blanchâtre domine tristement une plage base; ces dunes [...] sont d'une affreuse aridité; derrière elles, à une assez grande distance, une autre chaîne de collines couvertes de verdure borne [...]; entre les dunes et les collines règnent des marécages qui n'ayant aucun moyen de desséchement, exhalent les miasmes putrides qui envahissent toutes les contrées environnantes.

[...] la fièvre jaune sort de ces marais impurs pour être la terreur de l'étranger, elle défend le territoire mieux que ne le pourrait faire une armée: contre elle la bravoure est impuissante. La ville de Vera-Cruz, avec ses maisons et ses églises peintes de couleurs variées, ses fortifications blanches, semble comme perdue au milieu des sables qui l'entourent de tous côtés; à 800 mètres environ dans le N.N.E, sur un rescif, est placé le fort de San Juan de Ulùa, blanc comme la ville qu'il défend et qu'il domine avec son artillerie", en Dauzats y Blanchard, en San Juan de Ulúa, 65-66, trad. del autor. 
DOI: http://dx.doi.org/10.22201/iie.18703062e.2018.112.2632

242

ARTURO AGUILAR OCHOA

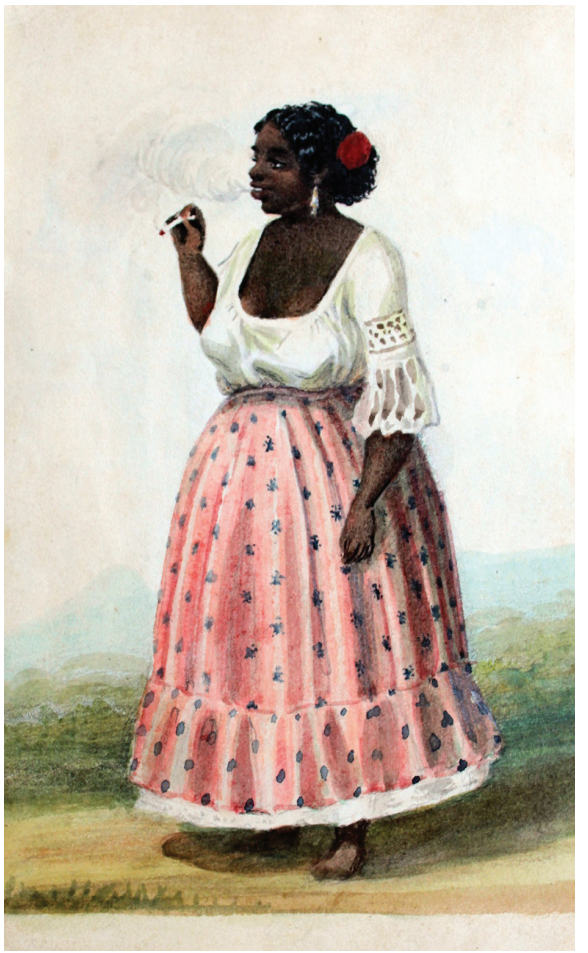

8. Petros Pharamond Blanchard, Negra fumando, I838, acuarela, I $8 \times I \mathrm{II}$. Colección A. Cristóbal.

más abundantes, y entre ellos se encuentran los personajes de origen africano que llamaron su atención como la conocida Negra fumando (fig. 8), se detiene en la sencilla vestimenta de la mujer con blusa blanca y falda de indiana estampada en rosa. El interés o el gusto por representar mujeres en todas sus gamas de color y vestimenta es notorio; como en el Grupo de mujeres apostadas en una puerta, envueltas en rebozos, y la figura de un niño desnudo a un lado; es evidente su preocupación por pintar las diferentes tonalidades de la piel, sobre todo, una de ellas que resalta por ser más oscura, lo mismo que Mujeres en el interior de una casa en diversas actividades (figs. 9 y Iо). La Vista del mercado es igualmente interesante, ya que era un lugar al que concurría una variedad de gente del pueblo, como las vendedoras de frutas, también envueltas en rebozos; lugares y escenas que le permitieron incluir figuras de pericos y monos que se comerciaban o servían de mascota a los vendedores, que al artista francés le han de haber parecido muy exóticos. Desde luego, la inclinación por pintar a 
9. Petros Pharamond Blanchard, Mujer del puerto jarocho, $\mathrm{I} 838$, acuarela, $\mathrm{I} 8 \times \mathrm{I} 2 \mathrm{~cm}$.

Colección A. Cristóbal.

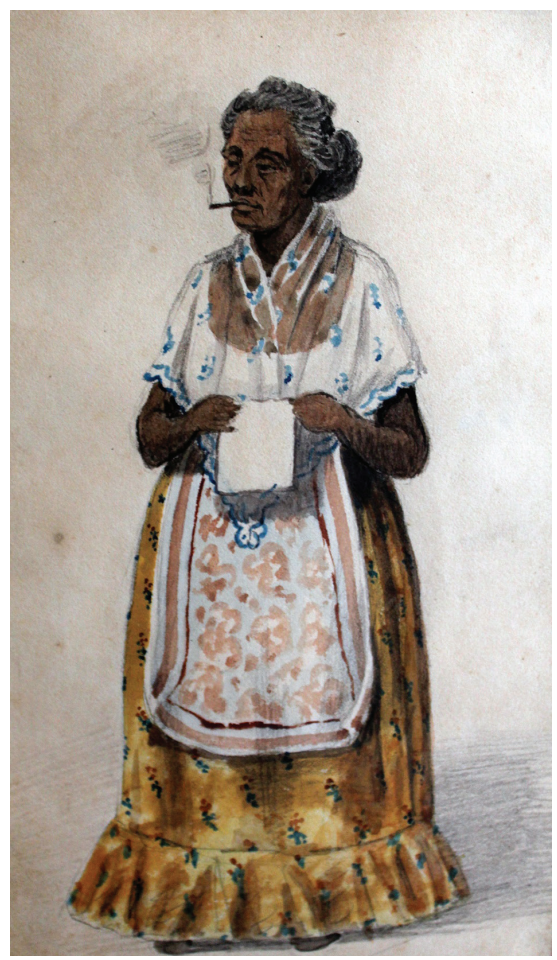

las mujeres y su vestimenta estaba muy en boga en el momento, con la aparición de los llamados tipos populares, como los jarochos que abundan en su obra. Existen, por ejemplo, cuadros con un minucioso trabajo en los detalles de la ropa, tanto de hombres como de mujeres; puedo seńalar el de una familia veracruzana, formada por el padre, la esposa y la hija que si bien deja ver deficiencias en el dibujo anatómico, en especial en la representación de los pies y el rostro, refleja muy bien el traje de esta región (fig. II). En su libro Blanchard describió el atuendo de los hombres que observa, cuando sale por el camino de Paso de Ovejas, y que le permite ver por primera vez a los que ya denomina jarochos. Según narra, era un domingo, y una gran población se extendía a lo largo del camino, uno de los sitios que le resulta más agradable del país, y describe la manera como se compone el traje: 


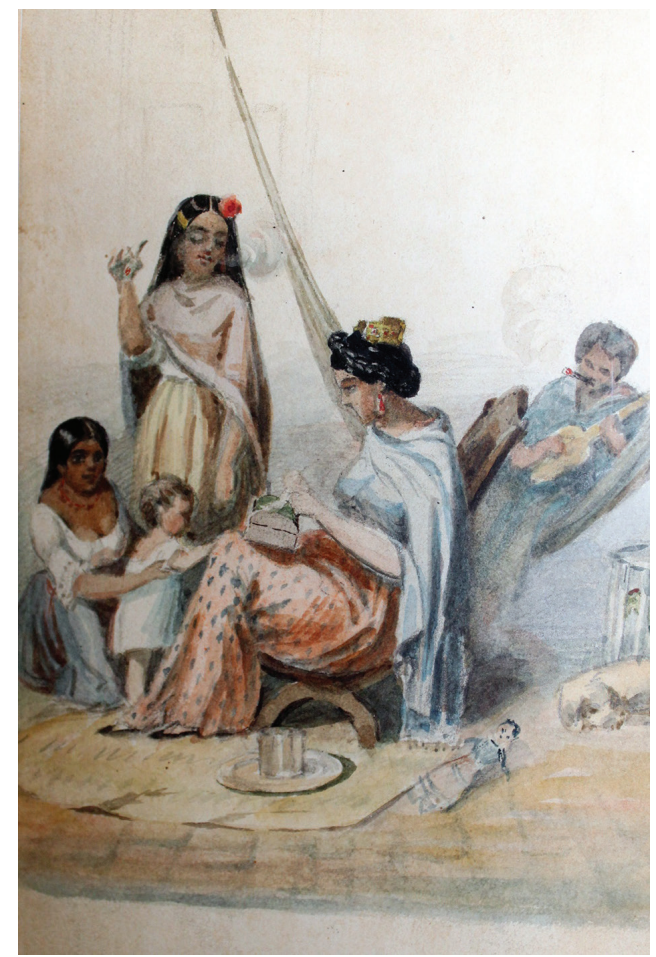

Io. Petros Pharamond Blanchard, Mujeres en el interior de una casa, 1838 , acuarela, I8 × II cm. Colección A. Cristóbal.

un pantalón blanco en bella tela de algodón, abierto desde la mitad del muslo, una camisa plisada en todo el cuerpo; un gran sombrero de alas anchas hecho también de fieltro blanco y botas ricamente bordadas con "arabescos" de una fineza extraordinaria: he aquí el traje de los elegantes en campańa. Casi todos están armados de machetes, que es una espada recta de una longitud media, que a más de servirles de defensa personal, también tiene la función para abrirse paso en medio de la maleza del bosque. ${ }^{59}$

59. "Un pantalon blanc en belle étoffe de coton, ouvert dès le milieu de la cuisse, une chemise plissée tout atour du corps, un immense chapeau à larges bords en feutre blanc, et des bottes richement brodées d'arabesques d'une finesse extraordinaire: voilà le costume des élégants des campagnes. Presque tous sont armés du machete, sabre droit d'une longueur moyenne, qui sert à plusieurs usages, outre leur défense personnelle; c'est avec cette arme qu'ils s'ouvrent un passage au milieu des plus épaisses forêts", en Dauzats y Blanchard, en San Juan de Ulúa, Ioo, trad. del autor. 
II. Petros Pharamond Blanchard, Familia veracruzana, $\mathrm{I} 838$, acuarela, $\mathrm{I} 8 \times \mathrm{I} 2 \mathrm{~cm}$.

Colección A. Cristóbal.

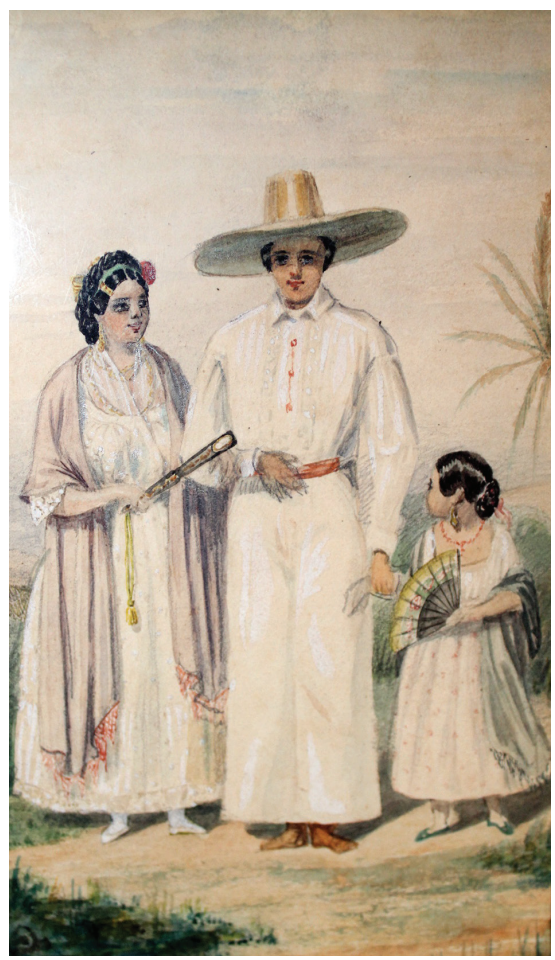

En esta visión del trópico también le llamó la atención que el traje se completara con el uso de los sarapes, la mayoría multicolores, y señala que en el Perú se les conocía como ponchos. Tanto en su descripción escrita, como en la plástica hay un detenimiento muy preciso en los trajes de las mujeres, por ello no es extraño que en los cuadros que tienen una mayor intención de representar una escena costumbrista, destaque esa presencia femenina, como las mujeres que se distinguen en el Paseo - hoy parque Zamora- o en las iglesias del puerto, donde se ven arrodilladas envueltas en coloridos chales. La aridez del paisaje que se percibe en el fondo de algunos de estos cuadros no deja duda que es el puerto, lo mismo que los zopilotes que revolotean en algunas escenas, que eran aves muy apreciadas en Veracruz, ya que tenían la función de limpiar las calles de la carroña o animales muertos. Pero sin duda la que para mí es una de las mejores estampas de Blanchard es la que se adivina pudo ser una joven y bella porteña que le llamó la atención. Se encuentra de perfil, con falda larga blan- 
ca, está envuelta en un rebozo y luce en el pelo la clásica peineta o cachirulo, hecho de concha nácar que dará origen al traje folklórico actual (fig. I2) y que coincide en parte, con la descripción que hace en su texto:

el traje de las mujeres es de una gran simplicidad; una blusa escotada de manera increíble; una enagua blanca en el borde inferior, y el resto de azul índigo, las piernas y los pies desnudos, tal es el vestido habitual; cuando viajan ellas se cubren la cabeza con un chal o echarpe, nombrado reboso, con dibujos de cuadros azules y blancos, de una tela ligera de lana o de algodón; ellas se envuelven graciosamente en los pliegues de su reboso. ${ }^{60}$

¿Cuáles eran los antecedentes del artista para realizar esta serie de tipos populares que pudieron servirle de referencia? Su propio trabajo en Espańa, sobre toreros y la fiesta en las plazas taurinas sin duda fue un excelente ejercicio y una empatía con el mundo hispano, pero también es posible que haya conocido el álbum de Claudio Linati, Trajes civiles, militares y religiosos, publicado en Bruselas, Bélgica en I828 y aún más probable es que haya tenido conocimiento del Viaje pintoresco y arqueológico, por la parte más interesante de México entre los años de I834 a I836, del alemán Carlos Nebel, el cual se había publicado en París en 1836 y en donde se incluyeron algunos tipos mexicanos. Sobre todo el trabajo de Nebel gozaba de enorme popularidad en estos años, pues además venía avalado por una introducción del barón Alejandro de Humboldt, quien hizo que se copiara muy pronto en México, y motivó incluso que su autor viniera a reclamar los derechos de la obra. Debido a este éxito, el arquitecto de Hamburgo decidió publicar otra edición en español para un público mexicano, justo en I838, pero su venta se retrasa hasta I840 precisamente por el bloqueo de los franceses. Llama la atención que un grabado de Blanchard en su libro lleve por título Monte virgen al igual que una litografía de Nebel, aunque la referencia pudo ser también la de Charles Othon Jean Baptiste conde Clarac (I777-1847). ${ }^{6}$ Fuera de ello, al revisar las pinturas no encuentro una evidente cercanía con los trabajos del arquitecto alemán; me atrevo a suponer que Blanchard estuvo más imbuido de la obra de Jean Baptiste Debret

6o. "Le costume des femmes est de la plus grande simplicité ; une chemise décolletée d'une façon incroyable, un jubon dont le haut est blanc, et le reste bleu d'indigo, les jambes et les pieds nus: tel est leur vêtement habituel. Lorsqu'elles voyagent, elles mettent sur leur tête un châle ou écharpe nommé reboso, à carreaux bleus et blancs, d'une étoffe légère de laine ou de coton; elles s'enveloppent gracieusement dans les plis du reboso", en Dauzats y Blanchard, en San Juan de Ulúa, Ior.

6r. El trabajo de este artista lleva por título Floresta virgen de Brasily fue realizado en I819. 
I2. Petros Pharamond Blanchard, Joven jarocha, I838, acuarela, $\mathrm{I} 8.5 \times \mathrm{I} 2 \mathrm{~cm}$.

Colección A. Cristóbal.

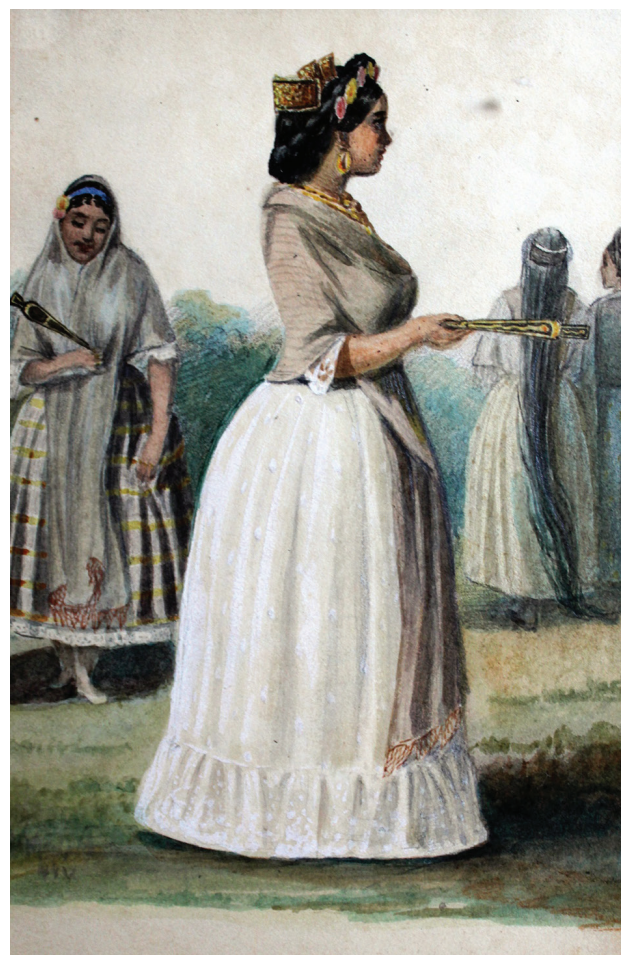

(I768-I848), quien había hecho un importante trabajo sobre los tipos de Brasil, obra que era también muy popular en Francia. En todo caso, todo ello alude a la búsqueda del exotismo en las regiones poco conocidas del mundo, una de las vertientes del romanticismo del cual, desde luego, no podía escapar Blanchard; no hay que olvidar que en un principio esa curiosidad la encauzó al Oriente, y en cierta manera a España, pero después intuyó que el campo era fértil en América, posiblemente una poderosa razón para aceptar el viaje en la expedición. El Voyage pittoresque et historique au Brasil, por ejemplo, empezó a publicarse desde I834 y se concluyó en I839 también en la capital francesa. En especial el volumen 3, dedicado "a la instrucción pública, cultos religiosos, acontecimientos políticos y personajes realistas" de la capital imperial como era Río de Janeiro, muestra muchas costumbres y actividades de los esclavos negros de esa ciudad. Resulta notoria, en la obra de Debret, la abundancia de vendedores callejeros en Río de Janeiro, aspecto que destaca Blanchard en Veracruz, como una característica que 
pudo atraer a los dos artistas franceses. En especial hay una escena de un cuadro de Blanchard donde se encuentra una multitud al parecer en un fandango en la calle, y en uno de los extremos aparece una mujer sentada amamantando a su hijo (fig. 13), que me recuerda otro cuadro de Debret, "Encuentro de matronas" con una esclava negra en la misma posición, dándole pecho a su hijo, en el extremo inferior izquierdo. Las diferencias apuntan más bien hacia al hecho de que las escenas suceden, una al interior y la otra en plena calle, pero la multitud variopinta y alegre es notoria en ambas. El hecho es que la variedad de tipos pocas veces se había pintado tanto en la región. Finalmente, puedo decir que todos estos cuadros son más que bocetos - como el de un negro con un amplio sombrero de paja, en el que apenas se dibujó la vestimenta pero en cambio hay un minucioso cuidado en el dibujo del rostro, o también el retrato a lápiz de un caballero, quizás veracruzano, con un gorro y bata de casa—, más próximos al dibujo trazado a vuela pluma, que a pinturas terminadas, ambas obras están impregnadas de un aire fugaz y espontáneo. Sin embargo, hay algunas excepciones en esta serie, pues existen cuadros cuya elaboración tal parece le llevó más tiempo. Uno de ellos se titula Vendedores con el Pico de Orizaba, que representa una escena al aire libre, en medio de una vegetación exuberante, de la que destacan varias plantas como un árbol de plátano, y está enmarcada por la amplia montańa cubierta de nieve, que llamaba mucho la atención de los viajeros. Del lado izquierdo, en un primer plano, se encuentra un grupo de vendedores de fruta, sentados mientras un jinete que se ve de espaldas se ha detenido, sin bajarse, a comprarles algo, figura que sobresale en la composición. La recreación de los detalles del sarape y de la ropa de los personajes demuestra el cuidado por hacer una obra más elaborada. De igual manera, las diferentes tonalidades del verde de la vegetación dan cuenta de una obra acabada, y de hecho explican por qué se presentó en una exposición de la Academia de Bellas Artes de Lyon al año siguiente, es decir en 1839. ${ }^{62}$ El colorido y la luz en el cuadro sintetizan de nueva cuenta dos de los principales aspectos presentes en varios de los pintores de la época y más aún si visitaron nuestro país; por un lado, el exotismo, del que ya se habló y que algunos autores han calificado de romanticismo tropical, ${ }^{63}$ que alimentaba, sobre todo, la idea de

62. Este dato lo cita Paul Guinard, Dauzats et Blanchard, 452. Incluso señala el título con el que se presentó en la exposición: Marchand de fruits au Mexique. Me fue difícil encontrar al coleccionista particular que ahora posee el cuadro y por ello no lo incluyo.

63. Quien ha acuńado este término entre otros investigadores es Ana Lucía Araujo en su libro: Brazil through French Eyes. A Nineteenth-century Artist in the Tropics (Alburquerque, Nuevo México: University of New Mexico Press, 2015), I24. 


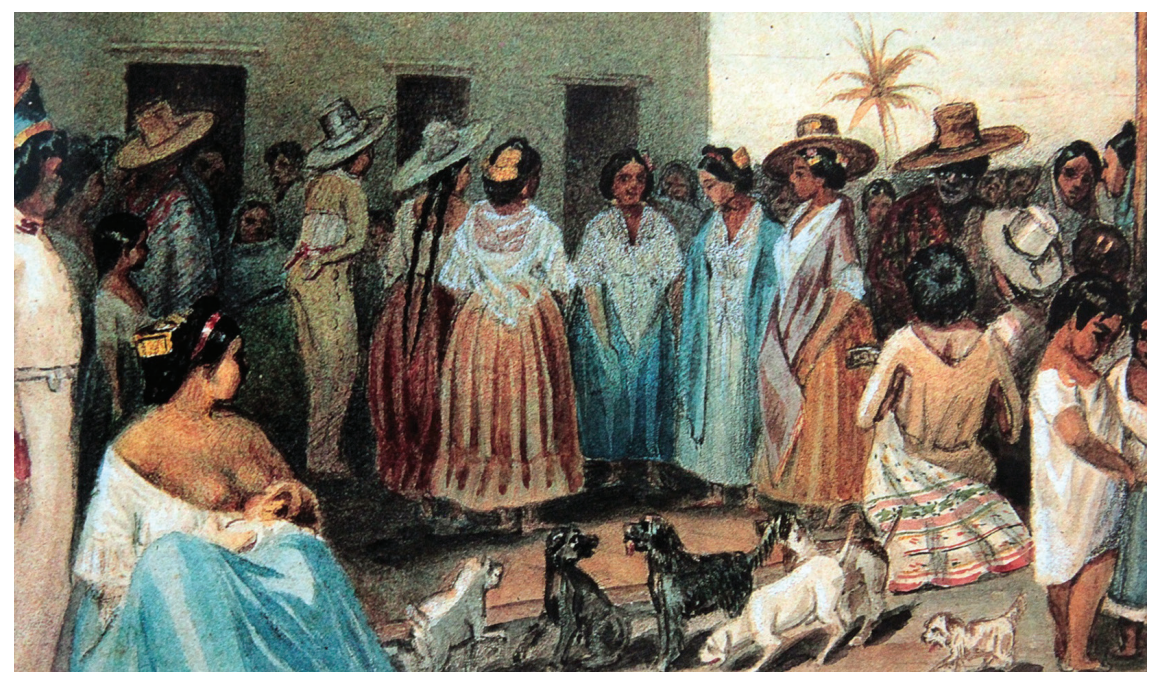

13. Petros Pharamond Blanchard, Fandango jarocho, I838, acuarela. Colección A. Cristóbal.

un mundo bello, por la flora y la fauna inmensamente ricas, pero también virgen e ignoto. Por el otro, un paisaje que presenta los diversos matices del territorio; por algo Blanchard divide en tres las zonas que visita, desde las costas de Veracruz hasta la Ciudad de México, dada su temperatura: tierra caliente (terre chaude), tierra templada (terre tempérée) y tierra fría (terre froide) lo que implicaba la variedad de climas y paisajes, que se deleita narrar en su libro. De hecho, cuando describe la orografía destaca que: "el calor es insoportable al pie de estas montañas alpinas, pero que en su punta están coronadas de nieves eternas; las temperaturas son de lo más variadas, de lo más opuestas, de las zonas tórridas a las regiones heladas, encontramos todas las flores que crecen y florecen en un clima que le es favorable y cubren a este país de la base de su paisaje, con una espléndida capa de colores abigarrados". ${ }^{64}$ Quizá por ello el interés en destacar las fronteras, como eslabones de la transición de estos espacios que fascinaban a todo viajero; de ahí pintar una montaña nevada con una flora tropical a sus pies que contrasta el clima frío y el caluroso. No obstante, al parecer Blanchard no tuvo el tiem-

64. "la chaleur la plus insupportable au pied de ces monts alpestres dont le front est couronné de neiges éternelles; les températures les plus variées, les plus opposées, depuis la zone torride jusqu'aux régions glacées, et toutes les plantes, toutes les fleurs qui croissent et s'épanouissent chacune dans le climat qui lui est favorable et couvrent de pays de la base au faîte, d'un splendide manteau aux couleurs diaprées", en Dauzats y Blanchard, en San Juan de Ulúa, 84, trad. del autor. 
po para elaborar más cuadros de esta catadura pues no se encuentra otro igual, a excepción de un paisaje que se presentó en el Museo de San Carlos y que Elisa García Barragán no dudó en calificar de soberbio, en el que de nueva cuenta se percibe esta intención de marcar las diferencias climáticas de las regiones. En este cuadro Blanchard pintó a un jinete que corre a todo galope, y cruza esas fronteras pues es notorio que sale de una especie de bosque o selva tropical, con abundantes árboles a un campo abierto en donde se distingue a lontananza una vegetación que ha cambiado notoriamente y que se asemeja más bien al paisaje de una sabana carente de vegetación; una palmera en el centro de la composición y al lado izquierdo unos troncos que al parecer han sido derribados, tienen la intención de marcar dos líneas que separan esos distintos climas (fig. I4). ${ }^{65} \mathrm{De}$ ahí que en la serie también se encuentran muchos detalles de la flora y de la fauna (fig. I5), incluso el dibujo de un escorpión y hasta el de un cocuyo o insecto luminoso (phyrophorus noctilucus), característicos de la zona que hablan del gusto del artista por registrar todo lo que ve, en ese afán científico de documentación tan caro a la Ilustración en el cual todavía se debatían los pintores románticos.

\section{Viñetas en el libro de San Juan de Ulúa}

Publicado al año siguiente de la expedición en 1839, el libro de San Juan de Ulúa ofrece una interesante y minuciosa descripción del país, que ya he señalado, sobre diferentes aspectos que podrían interesar entonces al público europeo. Este volumen, digno de destacar, no fue un trabajo improvisado, pues Blanchard se dio a la tarea de documentarse para lo cual se apoyó en autores como Antonio de Solís, en su obra Historia de la conquista de México, y el barón Alejandro de Humboldt, en su Ensayo político sobre el reino de la Nueva España, que le sirvieron para entender varias de las construcciones de la capital, o tener noticia de personajes; ambos escritos fueron una fuente interesante para la historia social, política y económica de México en esos años, apenas tomada en cuenta. Por ejemplo, en el libro menciona que conoció a Ashburnam, encargado interino de los negocios de Inglaterra en ausencia de Packhenhan, ministro oficial y en ese entonces encargado de proteger a los franceses pues no había representante de Francia. Al respecto Blanchard mencionó que:

65. La reproducción de este cuadro se puede ver en el catálogo de la exposición "Veracruz, los colores del sol”, I2. 


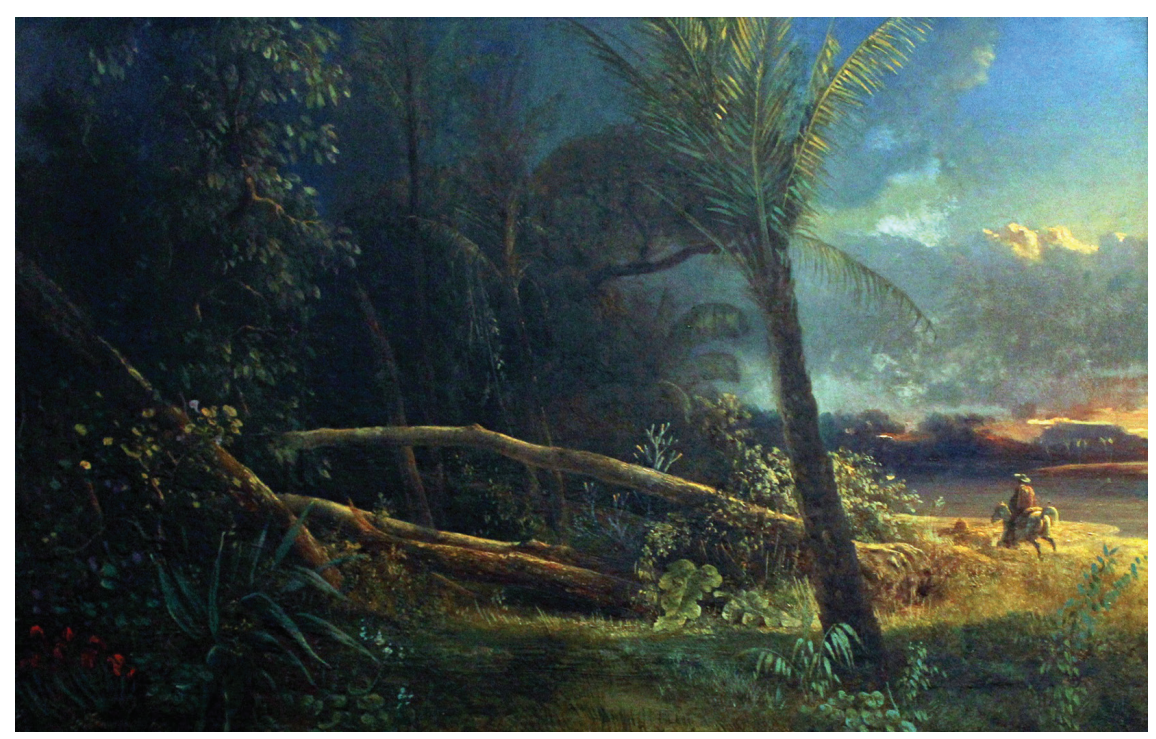

I4. Petros Pharamond Blanchard, Paisaje veracruzano, I838, óleo sobre tela. Colección A. Cristóbal.

yo vivo con el señor Ashburnam y el señor Mialhe, joven artista francés, que estaba establecido en México desde hace poco tiempo. Es el destino de Francia de lanzar a sus hijos a todas las naciones para propagar, por medio de misioneros iluminados, el gusto por las artes, o para popularizar los descubrimientos más importantes de la ciencia. El señor Mialhe cuyas litografías eran admiradas en su patria, partió de París con el noble designio de ir a naturalizar a dos mil leguas, los métodos litográficos; ni las dificultades del viaje aún más grandes por la obligación de transportar el material necesario, ni el personal nuevo que debía instruir llegando, lo frenaron, y fue el primero que tuvo la gloria de hacer participar a México de uno de las más grandes descubrimientos del siglo. ${ }^{66}$

66. "Je vis chez M. Ashburnan M. Mialhe, jeune artiste français, qui était depuis peu de temps établi au Mexique. Il est de la destinée de la France de lancer ses enfants chez toutes chez toutes les nations pour y propager, en missionnaires éclairés, le goût de arts, ou pour or vulgariser les découvertes les plus importantes de la science. M. Mialhe dont les litographies étaient justement admirées dans sa patrie, partit de Paris avec le noble dessein d'aller naturaliser à deux mille lieues les procédés litographiques; ni les difficultés du voyages rendues plus grande encore par l'obligation de transporter le matériel nécessaire ni le personnel nouveau qu'il dut instruire en arrivant, ne l'arrêtèrent, et le premier il eut la gloire de faire participer le Mexique à l'une de plus découvertes de ce siècle", en Dauzats y Blanchard, en San Juan de Ulúa, I68-I69, trad. del autor. 


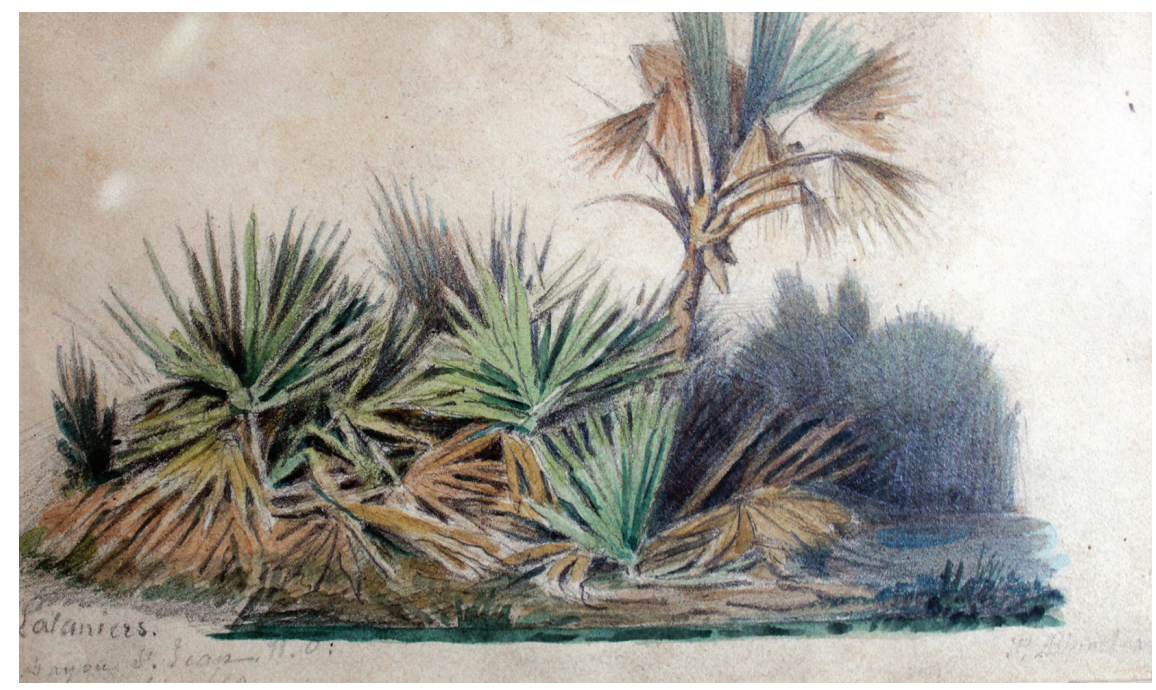

I5. Petros Pharamond Blanchard, Vegetación probablemente en el estado de Veracruz, I838, acuarela. Colección A. Cristóbal.

El joven artista al que se refiere Blanchard es seguramente Federico Mialhe (I8IO-I88I), cuya llegada algunos autores ubican en $1838,{ }^{67}$ no obstante que no le cabe la gloria, como dice Blanchard, de ser el primero en "hacer participar a México de uno de los más grandes descubrimientos del siglo" como era la litografía. De hecho, si se deja de lado la apología que hace de la Intervención francesa, se descubren interesantes viñetas, que también constituyen una valiosa referencia, las cuales se pueden clasificar en dos grupos: grabados grandes y grabados pequeños. Los primeros en página completa alusivos a los sucesos que narra, como Prise du Général Arista (la aprehensión del general Arista) (fig. I6) y los segundos por lo regular al principio o al final de cada capítulo, insertados en el mismo texto. Las viñetas grandes suman un total de $\mathrm{I} 8$, y su ejecución corresponde por mitad a Blanchard y

67. Quien ha dado cuenta de Mialhe ha sido Ricardo Pérez Escamilla. Este autor apunta que estableció su taller en 1838 asociado con José Decaen, véase "Arriba el telón. Los litógrafos mexicanos, vanguardia artística y política del siglo xIx", catálogo de exposición, Nación de imágenes. La litografía mexicana del siglo XIX (México: Museo Nacional de Arte, 1994), 23. Sin embargo, otras fuentes señalan que en este mismo año Mialhe estuvo en La Habana, Cuba, donde realizó un importante trabajo litográfico, así que estos datos abren nuevas fuentes a la investigación. 
a Dauzats, a excepción de una sola, hecha por Justin Ouvrier que representa un paisaje: Plan de Tepeyagualco. Es evidente la preferencia de Blanchard por escoger los episodios bélicos o del puerto de Veracruz, como el dibujo del Fuerte de San Juan de Ulúa o la explosión en la Torre del Caballero (Tour de Cavalier) y las escenas costumbristas con el título de Costumes Mexicains; a su vez Dauzats se inclinó por paisajes rurales del campo mexicano, como una vista del Ixtaccihuatl (sic) y el Popocatépetl, o de lugares como Jalapa o de la Ciudad de México: Calle del Puente del Espiritu Santo o Sagrario y Catedral de México. Es de destacar que en la primera de estas vistas - hoy calle de Isabel la Católica-, a pesar de que el autor no estuvo en el país, es fiel en representar la iglesia de La Profesa que se encuentra en esta calle, no así en el caso de su arquitectura; en cambio el Sagrario tiene mayor fidelidad en el dibujo y en el texto se señala que es de estilo churrigueresco. Sólo un grabado fue ejecutado por los dos artistas: Bal à Bord de l'Iphigénie (El baile a bordo del Ifigenia) (fig. I7). Si Dauzats contó con algunos bocetos proporcionados por su amigo Petros Pharamond para realizar estos grabados es un misterio que no se aclara en el libro, ni en la biografía hecha por Guinard, aunque me inclino a creer que así fue; lo cierto es que la calidad del dibujo y, sobre todo, la fidelidad a la realidad representada hacen del conjunto de grabados testimonios gráficos que después tomarán las revistas francesas. Las viñetas pequeñas a su vez están distribuidas en los 17 capítulos del libro, con dos grabados dedicados a cada uno de ellos, lo que da un total de 34 . Todas las realizaron Blanchard y Dauzats, e igualmente hay una preferencia del primero por los acontecimientos que tienen que ver de manera directa con la intervención francesa, de la cual fue testigo, como La llegada de los plenipotenciarios mexicanos, Entierro de M. Lambert, Tumbas de los marinos franceses en sacrificios o el Almirante y su Estado Mayor. Por su parte, Dauzats ejecutó paisajes rurales, como un Bosque virgen o Puente Nacional, y en especial vistas de ciudades o poblaciones como Las Vigas, Santa Gertrudis, Río Frío o San Miguel del Soldado. Son también muy fieles a la realidad del paisaje mexicano, con menos atisbos de una interpretación personal más notoria en los cuadros, lo que hace muy valiosos los grabados y quizá comparables sólo a lo que había hecho años antes Elizabeth Ward al ilustrar el libro de su esposo, Henry George, México en 1827, primer embajador británico en nuestro país. De hecho, eran los anglosajones quienes llevaban una ventaja en la publicación de libros sobre viajes a México, pues además de Ward, publicaron el estadounidense Joel Poinsett en I824, y sus compatrio- 
DOI: http://dx.doi.org/10.22201/iie.18703062e.2018.112.2632

254

ARTURO AGUILAR OCHOA

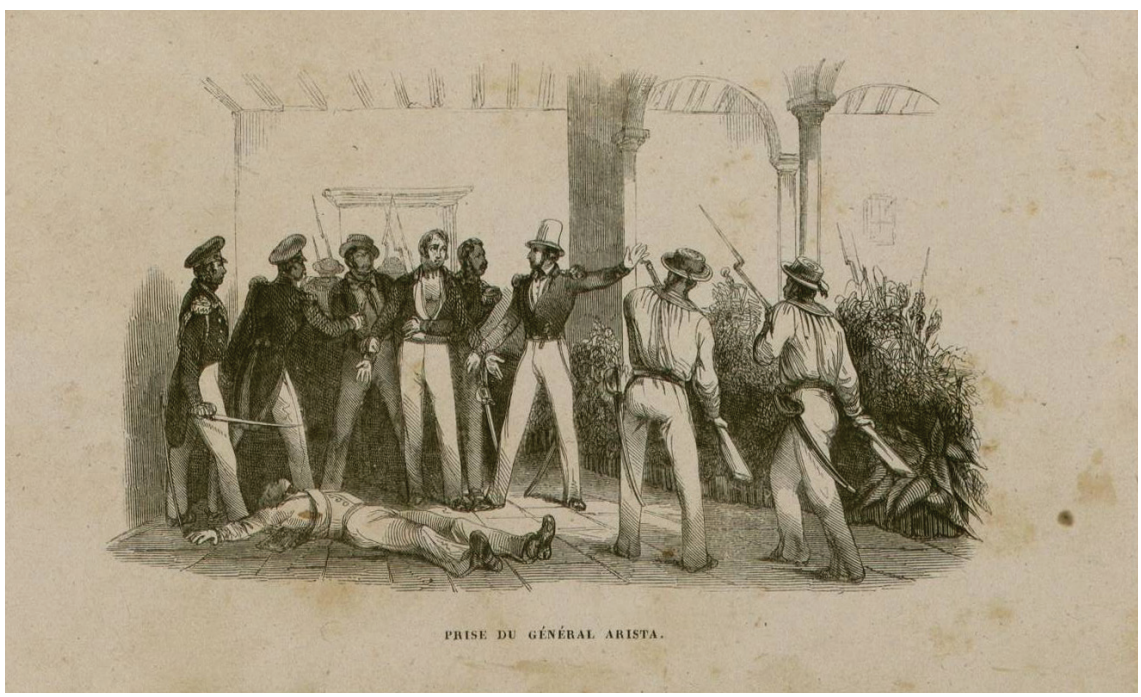

16. Petros Pharamond Blanchard, Prise du Général Arista, I839, grabado tomado de San Juan de Ulúa ou Relation de L'expédition Française au Mexique (París: Gide, I830), 37I. Biblioteca de la Universidad de Nuevo León.

tas William Bullock el mismo año, Basil Hall, en I825, R.W. Hardy en I828 y George Frances Lyon en $1828,{ }^{68}$ y aunque el francés Mathieu de Fossey se encontraba en la década de I830 en el país, será hasta I844 cuando publique su libro Viaje a México. ${ }^{69}$ No incluyo al barón de Humboldt y los álbumes litográficos de Claudio Linati (1828) y Karl Nebel (1836), pues entran en otra categoría o etapa, por tanto el libro de San Juan de Ulúa coloca a Blanchard como el primer francés, o al menos uno de los primeros, en escribir sobre nuestro país. Aunque no sabemos cuál fue la recepción del libro en Francia, sin duda sirvió para hacer propaganda a la expedición del rey Luis Felipe en la llamada guerra de los Pasteles, pero también para dar a conocer el paisaje y los tipos mexicanos al público galo.

68. Para un estudio de la mirada extranjera y sobre todo anglosajona en estos momentos, véase la introducción de Juan Ortega y Medina, Zaguán abierto al México republicano (I820-1830) (México: Universidad Nacional Autónoma de México, 1987).

69. Mathieu de Fossey, Viaje a México, pról. José Ortiz Monasterio (México: Consejo Nacional para la Cultura y las Artes/Mirada Viajera, 1994). 


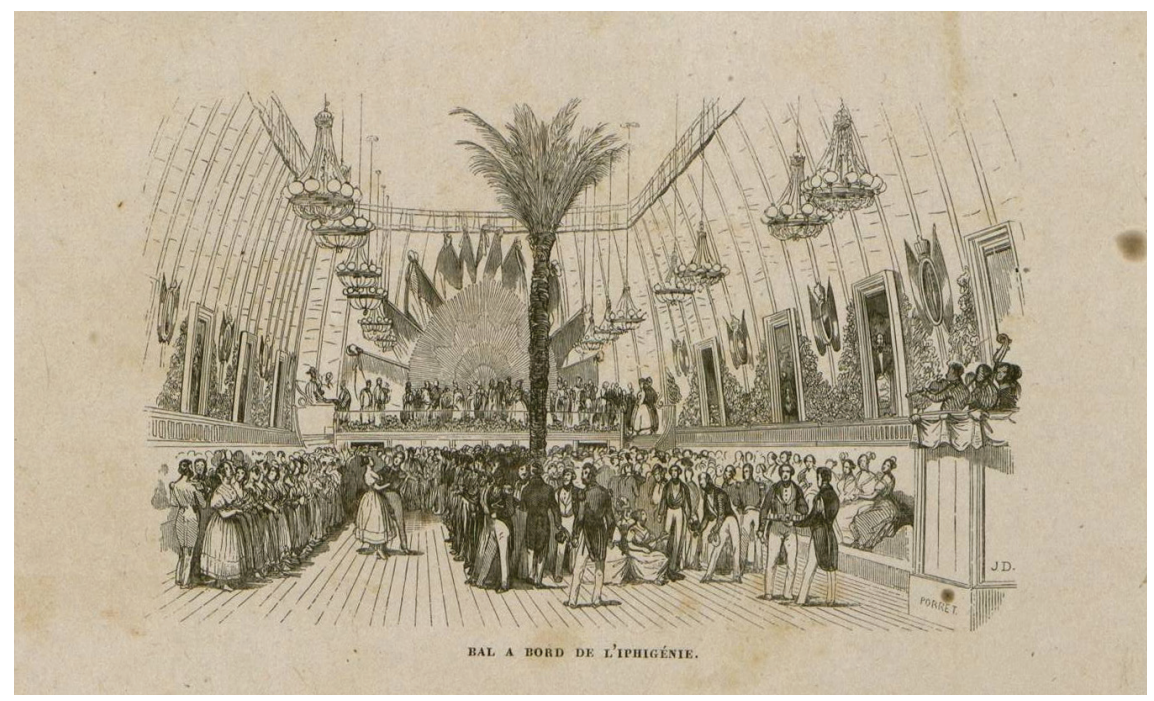

17. Petros Pharamond Blanchard y Adrian Dauzats, Bal à Bord de I’Iphigénie, I839, grabado tomado del libro San Juan de Ulúa ou Relation de L'expédition Française au Mexique (París: Gide, I830), 42I. Biblioteca de la Universidad de Nuevo León.

\section{Destino final de Blanchard}

La expedición a México termina, al menos para Petros Pharamond Blanchard, en diciembre de 1838 , cuando embarca de regreso a su patria, y después de hacer una escala en La Habana, llega a Francia el 27 de marzo de I839. A partir de entonces se dedica a preparar el libro, los cuadros de batalla y, según Guinard, entra en una etapa de estabilidad profesional. Recibe en mayo de I840 la medalla como Caballero de la Legión de Honor, seguramente en parte por su trabajo en México, que marca su regreso como artista en el medio parisiense. ${ }^{70}$ Exhibe algunos de los cuadros de la expedición en la Academia de Lyon; durante I2 años, es decir, de 1840 a I852, permanece en París, realiza viajes de corta duración en Francia o en países cercanos, como los que emprendió en I846 y I850, el primero en una misión oficial en ocasión de los matrimonios reales — de la reina Isabel II y su hermana la infanta Luisa Fernanda, casada con un hijo del rey Luis Felipe-, y el segundo a título perso-

70. Guinard, Dauzats et Blanchard, 89. 
nal. Vive por algún tiempo con sus padres, que habían regresado de Madrid, y después con Dauzats, en la calle Blanche $25 .^{7 \mathrm{I}} \mathrm{Se}$ sabe que el 7 de diciembre de I843 se casa en Notre-Dame-de-Lorette con una rica viuda, madre de dos hijos y que le lleva ocho ańos de edad: Caroline Reynaud de Barbarin, con la cual no procrea ningún hijo, pero que le permite vivir una vida más holgada en términos económicos, situación que se demuestra en el cambio de residencia a un barrio más elegante. Pese a ello, no abandona jamás la pintura, aunque a partir de entonces su participación en los salones será más discreta e irregular, donde por cierto presenta, según Guinard, escenas españolas, mexicanas y marroquíes. Entre ellos un cuadro histórico presentado en el Salón de I845 que lleva por título: Fernan Cortes sur la route de México, que habría de localizarse para estudiarlo.

Blanchard hizo algunos viajes importantes: uno a Oriente en 1852 y otro a Rusia de 1856 a I859, que le dieron materia para escribir libros, artículos y ejecutar cuadros, incluso de gran formato. De hecho, su biógrafo revisó el abundante material dibujístico con el que colaboró en el periódico L'Illustration, desde su fundación, además de notas con descripciones de sus recorridos. De su primer periplo a Egipto y Turquía, y gracias a las narraciones se tiene un itinerario minucioso, pues antes de su destino final visitó Italia, Grecia y Palestina entre otros lugares, por lo que es posible conocer el trayecto. Fruto de ello es el libro: Itinéraire Historique et descriptif de Paris à Constantinople, publicado en I855. Pero Guinard considera que tanto el texto, como las obras que mandó al periódico así como algunos cuadros derivados, como el Valle de Josafat, que figuró en la exposición universal de i855, no superan el trabajo hecho sobre México..$^{72}$ En cambio le parecen mejores las visitas que hizo en Rusia, que le permiten experimentar nuevas opciones del color, en esa tierra donde los inviernos le dan una nueva dimensión del paisaje; estas piezas tienen mayor aceptación en Francia, en parte por el contexto reciente de la guerra de Crimea. Visita ciudades como Moscú, Tiflis, San Petersburgo, que asimismo le dan material para escribir en el periódico L'Illustration. Gracias a los contactos que establece con algunos aristócratas rusos, recibe una invitación para realizar un viaje al Cáucaso, con el príncipe Barantinsky, quien ocupa un cargo importante en el gobierno del zar. La estancia durará más de seis meses, con lo cual

7I. Guinard, Dauzats et Blanchard. El padre de Blanchard muere en julio de I844 y la madre en 1858 .

72. Guinard, Dauzats et Blanchard, 93. 
Blanchard tiene la oportunidad de conocer lugares de esta región apenas tocados por otros europeos en sus pinturas, por lo mismo igual de pintorescos. El mismo príncipe le encarga una serie de acuarelas que registran estos paisajes de la Rusia zarista, con las que pretende formar una colección particular y otra parte regalarla a la emperatriz rusa. No olvida en estos trabajos sus reportajes gráficos sobre la vida rusa oficial y popular, tanto así que el periódico anuncia en julio de 1859 , el regreso de Blanchard a Francia. ${ }^{73}$

Aunque trató de conseguir el cargo de director de Bellas Artes, sin ningún éxito, los últimos años en la vida de Blanchard fueron de un trabajo intenso, pues siguió exponiendo su obra en los salones de París y colaborando en los periódicos, como la L'Illustration, Le Magasin Pittoresque y Tour du Monde, con grabados, en especial de los países que había visitado como Rusia, Egipto, España y, por supuesto, México. Una amplia galería de tipos populares pertenece a esta etapa, así como vistas de ciudades o paisajes de esas tierras. Realiza de hecho en 1865 un cuadro que lleva por título: L'Arriveé d'une division française à Plan del Rio, que compró por el Estado para el Museo de Chalon-sur Saône. ${ }^{74}$ Cabe destacar que sobre todo en los periódicos se han encontrado varios tipos populares mexicanos, como un habitante de San Blas, supongo Nayarit, y otro de una mujer de Acapulco, quizá solicitadas por los editorialistas, que representan de manera relativamente fiel a los habitantes de estos lugares, pues el hombre porta el traje con chaqueta corta y sarape y la mujer falda corta y envuelta en un rebozo, ${ }^{75}$ que asemeja mucho a las chinas poblanas; ambos con el colorido y los acuciosos detalles que hablan de un artista que conocía la vestimenta del país. Desde luego es muy posible que existan otras litografías más que faltaría localizar. No hay que olvidar que el momento era propicio para que Francia fijara los ojos en México, pues eran los años previos a la Intervención francesa de 1862 , de ahí que se recurriera a Blanchard que, aunque no estuvo

73. Guinard, Dauzats et Blanchard, 95-97.

74. Guinard sospecha por un documento que se encuentra en el archivo del Museo de Louvre, con fecha de 8 de abril de 1865 que el cuadro se compró en 200 francos, pese a que el pintor en ese momento no tenía graves dificultades financieras, Guinard, Dauzats et Blanchard, 99.

75. Una reproducción de estos grabados se encuentra en el México ilustrado, mapas, planos, grabados e ilustraciones de los siglos XVI al XIX, textos de Roberto L. Mayer, Antonio Rubial García y Guadalupe Jiménez Codinach, catálogo de la exposición (México: Fomento Cultural Banamex, 1994) I24. Los títulos de los grabados son: Costume de San Blas, Costume de Acapulco, y se imprimieron en el taller de Thierry. Roberto Mayer ubicó la fecha de su elaboración en I845, pero igual se publicaron posteriormente en algunos de los periódicos ilustrados que he mencionado. 
en todos los lugares que registra, contaba con apuntes y descripciones que le ayudaron a realizar estos dibujos. Nada extraño por demás, ya que la prensa francesa contactó a otros artistas que estuvieron en México para ilustrar sus artículos, como Claudio Linati o los franceses Eduardo Pingret o Phillipe Ronde. ${ }^{76}$ Se sabe, sin conocer exactamente las circunstancias, que Blanchard murió el ro de diciembre de 1873, en la calle de Lille, donde vivía con su esposa y su yerno. ${ }^{77}$ El periódico L'Illustration, donde tanto había colaborado, le dedicó una nota el 20 de diciembre de ese mismo ańo, escrita por un amigo apellidado Claretie, el cual califica al artista, como de una gran erudición y el más encantador de los hombres que había conocido, destaca sus viajes y escritos sobre el Oriente, Rusia, México, España y el Cáucaso. ${ }^{78}$ Gracias a este artículo también se tiene una imagen del artista que se incluyó en el texto, que constituye el único retrato, según el multicitado Guinard, que se conoce de Petros Pharamond, pero que lo representa ya como un hombre en la plenitud de la edad, quizá tomado de una fotografía, no joven como cuando llegó a México, a la edad de 33 años, con mayores ímpetus como artista. \$

76. Los artículos e imágenes mexicanas se encuentran en la prensa francesa, sobre todo poco antes de la intervención francesa y es un tema apenas estudiado por los historiadores.

77. Guinard, Dauzats et Blanchard, 99.

78. Guinard, Dauzats et Blanchard. 